\title{
The influence of Indian Ocean Dipole (IOD) on biogeochemistry of carbon in the Arabian Sea during 1997-1998
}

\author{
V V S S SARMA \\ SORST, Japan Science and Technology Agency, Kawaguchi, Japan and Hydrospheric Atmospheric \\ Research Center, Nagoya University, Nagoya 464 8601, Japan. \\ e-mail: sarma@hyarc.nagoya-u.ac.jp
}

\begin{abstract}
Data on ocean color chlorophyll $a(\mathrm{Chl} a)$ obtained using Sea-viewing Wide Field of view Sensor (SeaWiFS), sea surface temperature (SST) by Advanced Very High Resolution Radiometer (AVHRR), and sea surface height (SSH) by TOPEX/POSEIDON were analyzed to examine the influence of Indian Ocean Dipole (IOD) on the physical and biogeochemical processes with special reference to phytoplankton primary production and air-sea fluxes of carbon dioxide in the Arabian Sea. Positive SST anomalies (SSTA) were found in the Arabian Sea $\left(0.4\right.$ to $\left.1.8^{\circ} \mathrm{C}\right)$ with higher values in the southwestern Arabian Sea that decreased towards north. The SSH anomalies (SSHA) and turbulent kinetic energy anomalies (TKEA) suggest decreased mixing during the IOD compared to the normal period. Chlorophyll $a$ displayed significant negative correlations with SSTA and SSHA in the Arabian Sea. Consistently, Chl $a$ showed negative anomalies (low Chl $a$ ) during the IOD period which could be due to reduced inputs of nutrients. The photic zone integrated primary production decreased by $30 \%$ during the IOD period compared to the normal whereas $\mathrm{pCO}_{2}$ levels were higher (by 10-20 $\mu \mathrm{atm}$ ). However, sea to air fluxes were lower by $10 \%$ during the IOD period due to prevailing weaker winds. Primary production seems to be the key process controlling the surface $\mathrm{pCO}_{2}$ levels in the Arabian Sea. In future, the influence of IOD on ecosystem structure, export production and bacterial respiration rates are to be probed through in situ time-series observations.
\end{abstract}

\section{Introduction}

Between the mid 1997 and early 1998 months, an extreme climatic event associated with large sea surface temperature anomalies (SSTA) occurred in the Indian Ocean. Several studies have discussed the variability in sea surface temperature (SST) (Nicholls 1989; Behera et al 1999; Saji et al 1999; Webster et al 1999; Behera et al 2000; Iizuka et al 2000; Murtugudde et al 2000; Venzke et al 2000) and subsurface temperature (Tourre and White 1995; Meyers 1996; Murtugudde and Busalacchi 1999; Schiller et al 2000; Rao et al 2002) in the Indian Ocean. Saji et al (1999) referred to the differences in SST between eastern and western regions in the tropical Indian Ocean as the Indian Ocean Dipole (IOD) and showed that it significantly influences the rainfall in the Indian Ocean rim countries. In the beginning of July 1997, warmer SSTA were observed in the western but were colder in the eastern Indian Ocean. The cooling in the east resulted from the unusually strong upwelling along the equator and Sumatra. The western warming was initiated by weaker southwest monsoon winds and maintained by enhanced precipitation resulting in a barrier layer structure (Murtugudde et al 2000).

During the IOD events, SW monsoon winds are weaker along the Sumatra coast whereas stronger in the Arabian Sea and Bay of Bengal during

Keywords. Indian Ocean Dipole; biogeochemistry; carbon; chlorophyll; Arabian Sea; models. 
summer (Vinayachandran et al 2002). Therefore, the IOD events are a key to understand the underlying mechanisms responsible for climate change in the tropical Indian Ocean. However, the influence of these processes on biogeochemical cycling of carbon in the Indian Ocean is unknown. For instance, the efflux of $\mathrm{CO}_{2}$ to the atmosphere, chlorophyll $a(\mathrm{Chl} a)$, and primary production decreased by $>50-60 \%$ during El Niño compared to the normal period due to deepening of thermocline and nitracline that results in decreased supply of nutrients to the photic zone in the eastern equatorial Pacific (Feely et al 2002; Chavez et al 1999). Murtugudde et al (1999) observed significant changes in Chl a concentrations during the IOD events in 19971998 in the western Indian Ocean. They further observed that SeaWiFS Chl $a$ concentrations were not significantly different from that of CZCS (Coastal Zone Color Scanner) during October and November in the northwestern Arabian Sea. However, anomalously higher SeaWiFS Chl $a$ concentrations were found during December 1997 and January to February 1998 in the northwestern Arabian Sea compared to CZCS (1979-1986) that were attributed to enhanced entrainment fluxes into the mixed layer (Murtugudde et al 1999). Jabaud-Jan et al (2004) observed significant differences in airsea flux of $\mathrm{CO}_{2}$ during austral summer between 1998 and 2000 in the subtropical Indian Ocean. The $\mathrm{pCO}_{2}$ levels were higher during January 1998 by $20-40 \mu \mathrm{atm}$ than in 2000 . As a result the subtropical region acted as a source of $\mathrm{CO}_{2}$ to the atmosphere $\left(2 \mathrm{mmol} \mathrm{m}^{-2} \mathrm{~d}^{-1}\right)$ during 1998 but as a sink for atmospheric $\mathrm{CO}_{2}\left(-1 \mathrm{mmol} \mathrm{m}^{-2} \mathrm{~d}^{-1}\right)$ during the normal period. Recently Baker et al (2006) compared 13 transport models to examine interannual variability in regional $\mathrm{CO}_{2}$ fluxes from 1988 to 2003. They found that significant increase in $\mathrm{CO}_{2}$ fluxes occurred from the tropical Indian Ocean during 1997-98. However, they have not considered interannual variability in wind speeds in their comparison.

Unfortunately, biogeochemical cycling of carbon is poorly understood in the equatorial Indian Ocean. A few studies were carried out during International Indian Ocean Expedition (IIOE), and Geochemical Section Study (GEOSECS) in the early 1960 s to 1970 s, respectively, on the biogeochemistry of carbon in the Indian Ocean. Recently, a considerable amount of hydrography, nutrients and inorganic carbon data have been collected under World Ocean Circulation Experiment (WOCE) program in the Indian Ocean during mid 1990. Based on this study, Sabine et al (2000) found that Indian Ocean (north of $35^{\circ} \mathrm{S}$ ) acts as mild sink for atmospheric $\mathrm{CO}_{2}$ $\left(-0.15 \mathrm{PgC}^{-1}\right)$. Unfortunately, no biological data

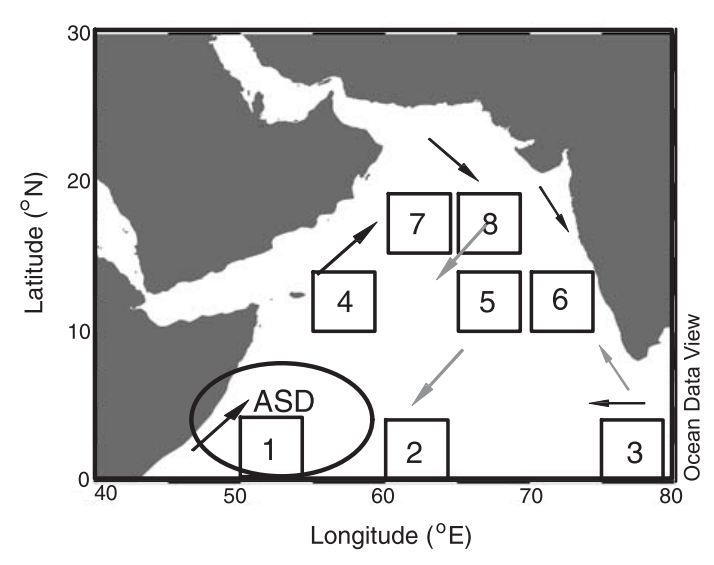

Figure 1. Schematic diagram showing the study region with wind directions during different seasons (dark arrows for SW monsoons and grey arrows for NE monsoon). Different boxes considered to examine monthly variability in physical and biogeochemical parameters are shown. The region of Arabian Sea Dome (ASD) is also shown according to Prasad and McClean (2004). Northwestern and southeastern upwelling regions are highlighted as dotted regions.

were collected during WOCE. No efforts have been made so far to understand either seasonal or interannual variability in biogeochemical parameters in the equatorial Indian Ocean. On the other hand, the international Joint Global Ocean Flux Study (JGOFS) facilitated a systematic study on quantitative understanding of carbon cycling in the Arabian Sea (northwestern Indian Ocean) during mid 1990s (figure 1). These studies revealed that upwelling during southwest (SW) monsoon (June to September), convective mixing in northeast (NE) monsoon (December to February) and bacterial respiration in intermonsoon supplies annually $70-90 \mathrm{TgC}$ as $\mathrm{CO}_{2}\left(1 \mathrm{Tg}=10^{12} \mathrm{gC}\right)$ to the atmosphere from the Arabian Sea (north of $10^{\circ} \mathrm{N}$ ) (Sarma 2003). Physical and biological processes mainly control the strength of this source (Sarma et al 2000). The intense upwelling processes make this region the largest oceanic source of $\mathrm{CO}_{2}$ to the atmosphere. The $\mathrm{CO}_{2}$ flux per unit area in the Arabian Sea is almost equal to that in the equatorial Pacific ( 2 to 3 mole $\mathrm{CO}_{2} \mathrm{~m}^{-2} \mathrm{~d}^{-1}$; Takahashi et al 2002). Unlike in the equatorial Pacific, where the export of biological production ( 800 to $1000 \mathrm{TgC}^{-1}$ ) is almost equal to the flux of $\mathrm{CO}_{2}$ to the atmosphere (700 to $1500 \mathrm{TgC}^{-1}$; Le Borgne et al 2002), the export production $\left(140 \mathrm{TgC}^{-1}\right.$; Sarma 2004) is almost double to that of the $\mathrm{CO}_{2}$ evasion at the air-water interface $(70$ to $90 \mathrm{TgCy}^{-1}$; Sarma 2003) in the Arabian Sea. This difference is mainly driven by phytoplankton community structure as the equatorial Pacific (both warm pool and upwelling areas) is characterized by the dominance of smaller phytoplankton 
(picoplankton of $<2 \mu \mathrm{m}$ size) (Chavez et al 1996), therefore the steady state is achieved by the balance between predation and growth. On the other hand, diatoms are the predominant among phytoplankton community in the Arabian Sea during monsoon seasons (December to February and June to September) resulting in higher export production (Buesseler et al 1998; Lee et al 1998; Honjo et al 1999).

Sarma et al (2000) found that higher surface $\mathrm{pCO}_{2}$ levels in the surface layers were mainly a result of vertical mixing at the base of the mixed layer in the Arabian Sea. Prasad and McClean (2004) found negative sea surface height anomaly (SSHA) across the southern Arabian Sea. They attributed that these were the manifestation of the sea level associated with the cold Arabian Sea Dome (ASD) during the normal period. They further found that absence of ASD during the IOD period is a result of prevailing downwelling rossby waves. Shukla (1987) found that most of the warm ENSO events are associated with weaker than normal summer monsoon over India. The changes in monsoon intensity and vertical mixing during the IOD period might have significant impact on biogeochemical cycling of carbon in the Arabian Sea as vertical mixing significantly affects surface $\mathrm{pCO}_{2}$ levels, and biological production through injection of $\mathrm{CO}_{2}$ and nutrient rich waters to the photic zone respectively. Unfortunately, no time-series measurements of biogeochemical parameters were carried out to understand the influence of climatic events on carbon cycling and air-sea interaction in the Arabian Sea. The objective of this manuscript is to examine how these climatic events, such as IOD, affect physical processes and influence biogeochemical cycling of carbon, with special emphasis on primary production and sea-to-air exchange of $\mathrm{CO}_{2}$, in the Arabian Sea through empirical models.

\section{Model}

Based on the changes in remote sensing SST, Chl $a$, and climatological salinity, it is possible to compute inorganic carbon parameters (such as dissolved inorganic carbon (DIC), total alkalinity (TA) and partial pressure of carbon dioxide $\left(\mathrm{pCO}_{2}\right)$; Sarma 2003) and primary production in the photic zone (Sarma 2005) using empirical models in the Arabian Sea.

2.1 Estimation of DIC, TA, $\mathrm{pCO}_{2}$ and sea-to-air fluxes in the Arabian Sea

The $\mathrm{pCO}_{2}$ in the seawater is a function of temperature, salinity, DIC, and TA. In general, small changes in salinity and TA occur in the surface waters, therefore, $\mathrm{pCO}_{2}$ changes are primarily governed by changes in temperature, biological activities, and DIC. Both DIC and $\mathrm{pCO}_{2}$ are influenced by four processes, such as biological activities (production and respiration), mixing with subsurface waters, solubility in seawater, and exchange at the air-sea interface. Recently, Sarma (2003) constructed multiple linear regression equations for the computation of DIC in the Arabian Sea using international JGOFS, World Ocean Circulation Experiment (WOCE), and Land Ocean Interaction and Coastal Zone (LOICZ) data sets and SST, sea surface salinity (SSS), and sea surface Chl $a$ as constraints. The resultant regression fits are:

$$
\begin{aligned}
\mathrm{DIC}= & 845.74-20.88 \mathrm{SST}+47.79 S \\
& -34.37 \mathrm{Chl} a[\text { December, January, } \\
& \text { February }], \\
\mathrm{DIC}= & 1071.6-17.471 \mathrm{SST}+39.23 S \\
& -31.478 \mathrm{Chl} a[\text { March, April, May }], \\
\mathrm{DIC}= & 1454.4-23.1 \mathrm{SST}+33.37 \mathrm{~S} \\
& -23.82 \mathrm{Chl} a[\mathrm{June}, \text { July, August }], \\
\mathrm{DIC}= & 865.5-7.6 \mathrm{SST}+37.8 S-37.9 \mathrm{Chl} a \\
& {[\text { September, October, November }], }
\end{aligned}
$$

where SST is sea surface temperature $\left({ }^{\circ} \mathrm{C}\right), S$ is salinity and $\mathrm{Chl} a$ is sea surface chlorophyll $a$ $\left(\mathrm{mg} \mathrm{m}^{-3}\right)$.

The alkalinity can be derived using salinity (Goyet et al 1999).

$$
\mathrm{TA}=350.8+55.6 S .
$$

Using DIC, TA and dissociation constants of Mehrbach et al (1973), which were refitted by Dickson and Millero (1987), and climatological nutrients, $\mathrm{pCO}_{2}$ was computed using $\mathrm{CO}_{2}$ sys program (Lewis and Wallace 1998). The errors involved in the computation of $\mathrm{pCO}_{2}$, from modeled DIC and TA couple, varied from \pm 5 to $30 \mu \mathrm{atm}$ and the larger errors are mainly associated with coastal regions whereas they are mostly $<10 \mu \mathrm{atm}$ in the open sea region.

The flux of $\mathrm{CO}_{2}$ at the air-water interface was computed using monthly mean $\mathrm{pCO}_{2}$ in each grid, wind speed, and solubility of $\mathrm{CO}_{2}$ using

$$
\mathrm{F}_{\mathrm{CO}_{2}}=k s\left[\mathrm{pCO}_{2 \text { water }}-\mathrm{pCO}_{2 \text { air }}\right],
$$

where $k$ is transfer velocity $\left(\mathrm{cm} \mathrm{h}^{-1}\right), s$ is solubility of $\mathrm{CO}_{2}$ in seawater (Weiss 1974), $\mathrm{pCO}_{2 \text { water }}$ 
and $\mathrm{pCO}_{2 \text { air }}$ are $\mathrm{pCO}_{2}$ in surface seawater and air respectively. The transfer velocity $k$ was computed according to Wanninkhof (1992)

$$
k=0.39 u^{2}\left[\frac{S c}{660}\right]^{-0.5}
$$

where $u$ is wind speed $\left(\mathrm{m} \mathrm{s}^{-1}\right)$ and $S c$ is the kinematic viscosity of water divided by the diffusion coefficient for $\mathrm{CO}_{2}$ (i.e., Schmidt number). Although there are several formulations to estimate transfer velocity, I believe Wanninkhof (1992) formulations will be more appropriate to the Arabian Sea since it agrees well with chlorofluorocarbons (CFC) observations in the northern Indian Ocean (Haines et al 1997). The $\mathrm{pCO}_{2 \text { water }}$ is the monthly average value of each grid point and the atmospheric $\mathrm{pCO}_{2}$ value $\left(\mathrm{pCO}_{2 \text { air }}\right)$ was taken from Goyet et al (1998) for the year 1995 and added $1.5 \mu \mathrm{atm}$ per year as the growth rate of surface $\mathrm{pCO}_{2}$ (Dore et al 2000; Bates 2001) to compute for years 1997 to 1999 .

\subsection{Estimation of photic zone integrated primary production}

In general, primary production is a function of light, nutrients, and Chl $a$ concentrations in the photic zone. Due to availability of a high amount of light, this will not limit primary production in the study region (Barber et al 2001). On the other hand, availability of nutrients (such as nitrate) plays an important role in primary production in the Arabian Sea (Qasim 1982; Barber et al 2001). Nutrients are brought to the surface layers mainly by mixing with subsurface waters and it occurs through convective mixing during NE monsoon and upwelling during SW monsoon (de Sousa et al 1996; Morrison et al 1998). Therefore, temperature can be used as a proxy for nutrient injection to the photic zone. The mixed layer depth is mostly deeper than photic zone depth except during intermonsoon period (March to May and October) in the Arabian Sea. About $70-100 \%$ of production occurs within the mixed layer where about $>20 \%$ of surface photosynthetically active radiation (PAR) is available. Therefore, surface Chl $a$ concentrations can be used as an indicator of production in the photic zone. The primary productivity data collected since mid 1980's to 1995 , including from International JGOFS experiments, in the Arabian Sea showed strong positive relation between surface Chl $a$, and photic zone integrated production whereas negative correlation with SST $\left(r^{2}=0.91\right.$; Sarma 2005). There was no significant relationship found between PAR and integrated production in the Arabian Sea $\left(r^{2}=0.02\right)$ which suggests that light does not limit primary production in the study region. Though the productivity data has been available since the early 1960s in the Arabian Sea, in order to avoid methodological bias in the data, only recent data were used in this study as it was collected following the same primary productivity protocol. Using these relations, Sarma (2005) derived an empirical relation to compute photic zone integrated primary production $\left(\mathrm{PP}_{\text {photo }} ; \mathrm{mmol} \mathrm{C} \mathrm{m}^{-2} \mathrm{~d}^{-1}\right)$ for the Arabian Sea using SST and surface Chl $a$.

$$
\begin{aligned}
\mathrm{PP}_{\text {photo }}= & 1862.66+1358.12 \text { Chl } a \\
& -57.25 \mathrm{SST} .
\end{aligned}
$$

The photic zone integrated production was computed using monthly mean SeaWiFS Chl $a$, and AVHRR SST from 1997 to 1999. The computed photic zone production using equation (8) is found to have an error of up to $15-20 \%$. The primary production estimated using this method gives the rate of ${ }^{14} \mathrm{C}$ assimilation into particulate organic carbon or net particulate organic carbon production in the photic zone.

Both DIC and primary production are influenced by physical (described by variations in SST) and biological processes (denoted by variations in Chl $a$ ). Therefore, the interannual variations in $\mathrm{SST}$ and Chl a can reflect their influence on the distribution of computed parameters. Hence, these statistical models would help us to understand how climate variations in physical and associated biological processes affect $\mathrm{CO}_{2}$ air-sea exchange and primary production in the study region.

\subsection{Validation}

In order to validate DIC, TA and PP models, I used in situ data collected during USJGOFS Arabian Sea Process Study (ASPS) program. Figure 2(a) shows monthly mean SeaWiFS Chl $a$ concentrations averaged over $1 \times 1^{\circ}$ box at $19^{\circ} \mathrm{N}, 67^{\circ} \mathrm{E}$ (Station N7) and $10^{\circ} \mathrm{N}, 65^{\circ} \mathrm{E}$ (Station S15) in 1998 and compared with measured Chl $a$ (flurometer) in 1995 during ASPS (Barber et al 2001). I have selected these two stations, as the interannual variations are relatively small in the central Arabian Sea (see results and discussion section). The agreement between the two data sets is quite good considering the fact that the cruise data are real-time, whereas the satellite data are monthly averages (figure 2a). The SeaWiFS Chl $a$ concentrations during summer are much lower than observed during ASPS probably due to the large short-term variations in Chl a concentrations. Naqvi et al (2002) found that surface Chl $a$ varied from 0.04 to $1.32 \mathrm{mg} \mathrm{m}^{-3}$ in 12 days at $21^{\circ} \mathrm{N}$ and $64^{\circ} \mathrm{E}$ during 

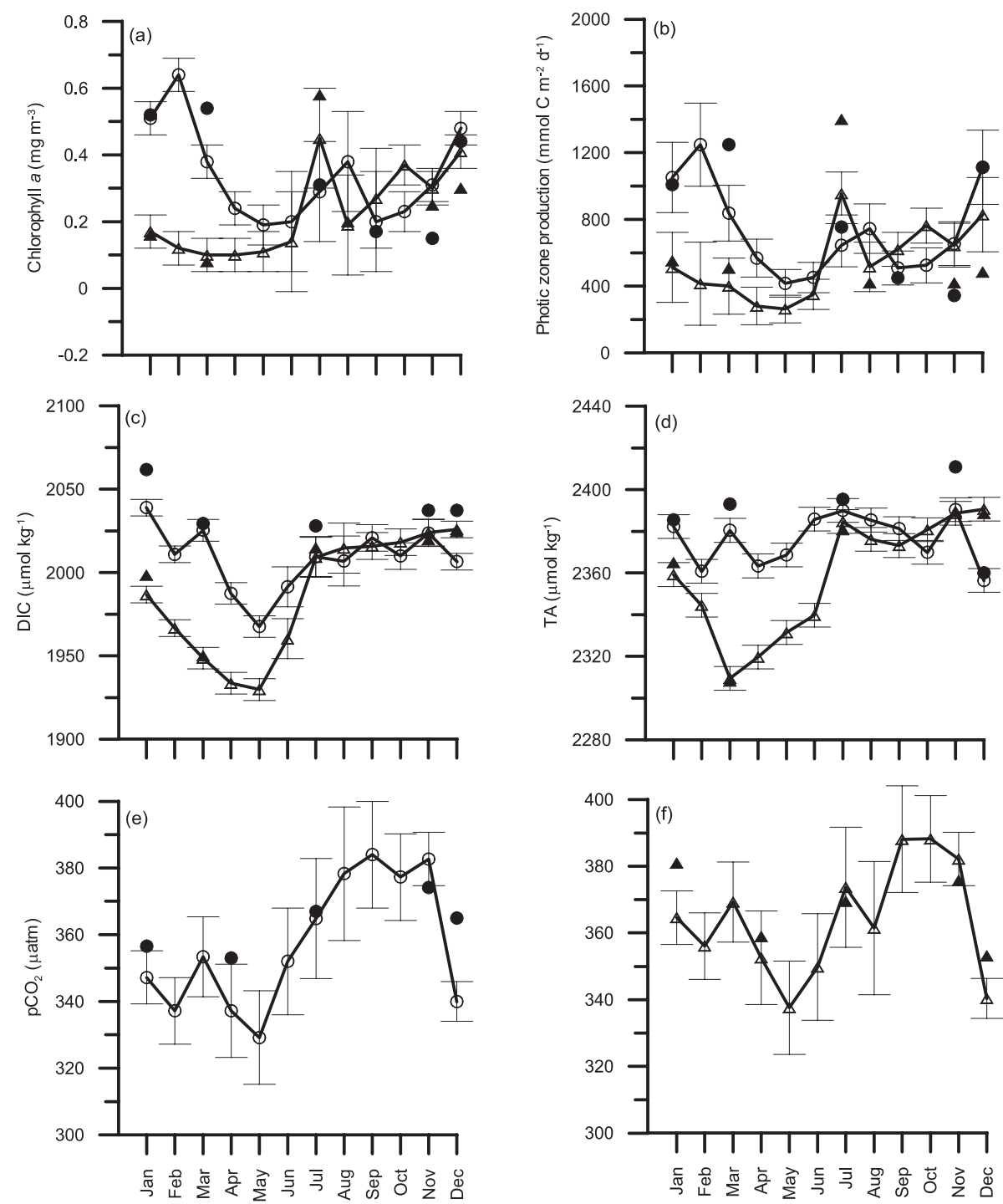

Figure 2. Comparison of (a) satellite Chl $a\left(\mathrm{mg} \mathrm{m}^{-3}\right)$, (b) photic zone integrated primary production $\left(\mathrm{mmol} \mathrm{Cm}^{-2}\right.$ $\left.\mathrm{d}^{-1}\right)$, (c) dissolved inorganic carbon $\left(\mu \mathrm{mol} \mathrm{kg}{ }^{-1}\right),(\mathbf{d})$ total alkalinity $\left(\mu \mathrm{mol} \mathrm{kg}{ }^{-1}\right)$ (e) pCO $\mathrm{e}_{2}(\mu \mathrm{atm})$ at station $\mathrm{N} 7$, and (f) $\mathrm{pCO}_{2}(\mu \mathrm{atm})$ at station $\mathrm{S} 15$ with in situ measured data during ASPS during 1995 at $19^{\circ} \mathrm{N}, 67^{\circ} \mathrm{E}(\mathrm{station}$ $\mathrm{N} 7$; closed circles) and $10^{\circ} \mathrm{N}, 65^{\circ} \mathrm{E}$ (station S15; closed diamonds) whereas open circles and open diamonds are satellite data respectively. The vertical bars on satellite Chl $a$ were derived from variations in weekly composites in a month.

February 1997 due to changes in grazing pressure by Salps. In addition to this, intensity of vertical mixing also seems to be different, as observed SSTs are cooler during summer and warmer during winter compared to satellite SST. The estimated photic zone productivity also showed good agreement with the measured production at two locations in the Arabian Sea within the errors involved (figure 2b).

Figure 2(c-f) shows monthly mean modeled DIC, TA and $\mathrm{pCO}_{2}$ levels averaged for $1 \times 1^{\circ}$ box at $19^{\circ} \mathrm{N}, 67^{\circ} \mathrm{E}$ and $10^{\circ} \mathrm{N}, 65^{\circ} \mathrm{E}$ using satellite data of the year 1998 and compared with measured DIC, TA and underway $\mathrm{pCO}_{2}$ data collected during 1995 ASPS cruises (stations N7 and S15; Millero et al 1998; Goyet et al 1998). The agreement is good as differences between them (real time and monthly averages) are to be expected. The modeled DIC and $\mathrm{pCO}_{2}$ levels during winter are lower than observed during ASPS cruises probably due to either differences in physical forcing or short-term variations in $\mathrm{pCO}_{2}$. The SST during winter 1998 was about 0.4 to $0.6^{\circ} \mathrm{C}$ warmer than during 1995 suggesting less intense mixing during the former period. In addition to this, Sarma (1998) found short-term variability in DIC and $\mathrm{pCO}_{2}$ to be as high as $5-10 \mu \mathrm{M}$ and $20-40 \mu \mathrm{atm}$ respectively at $21^{\circ} \mathrm{N}, 64^{\circ} \mathrm{E}$ during February 1997 , in 12 days period due to changes in physical and biological processes. Nevertheless, the modeled DIC, TA and $\mathrm{pCO}_{2}$ levels are in good agreement with the measured levels at two locations in 
the Arabian Sea within the errors involved in the estimations.

\subsection{Constraints of the model}

The constraints of the $\mathrm{pCO}_{2}$ and $\mathrm{PP}$ models are monthly means of SST, SSS, and Chl $a$. The monthly mean global images $(9 \times 9 \mathrm{~km}$ resolution) of AVHRR (Advanced Very High Resolution Radiometer) sea surface temperature data were obtained from NASA/JPL PO-DAAC PATH FINDER data base (http://podaac.jpl.nasa.gov/ sst/) whereas SeaWiFS (Sea-viewing Wide Field of view Sensor) version 4 chlorophyll $a$ data for monthly composite global standard mapped images $(9 \times 9 \mathrm{~km}$ resolution $)$ were downloaded from NASA GSFC's Distributed Active Archive Center (DAAC). The climatological salinity data were taken from National Oceanographic Data Center (http://ingrid.Ideo.columbia.edu/ SOURCES/.NOAA/.NODC/.WOA98/) (Conkright et al 1998). Both SST and Chl a data were taken at $0.25^{\circ} \times 0.25^{\circ}$ grid levels for the years 1997 to 1999 whereas SSS data were interpolated to the same grid from $1^{\circ} \times 1^{\circ}$ climatological data. Reynolds/NCEP SSTA, which is an optimally interpolated SST data set based upon a combination of AVHRR satellite and in situ were used. The anomaly was computed from monthly means of 1981 to 2005. The SSHA data were taken from TOPEX/POSEIDON and they are differences from the 9-year mean. The monthly mean wind speed data were obtained from ERS-2. All these data were obtained from http://poet.jpl.nasa.gov. The Chl $a$ anomaly (CHLA) are computed from 8-year mean from 1997 to 2004 using OCTS (19961997) and SeaWiFS (1997-2004) ocean color data.

\subsection{Model limitations}

The present model has some limitations in the estimation of $\mathrm{pCO}_{2}$ and air-sea fluxes of $\mathrm{CO}_{2}$. The major limitation arises from the assumption of insignificant interannual variations in SSS and nutrients as climatological fields were used. Despite knowing the fact that such changes are expected during IOD period, due to reduced vertical mixing, their magnitudes are unknown. On the other hand, Jabaud-Jan et al (2004) observed no significant variations in salinity during the IOD and normal period in the south Indian Ocean whereas the change in salinity during and after El Niño was 0.4 units in the equatorial Pacific (Feely et al 2002). If I assume that half of the salinity changes in the equatorial Pacific to occur in the Arabian Sea due to IOD that would lead to change in computed surface $\mathrm{pCO}_{2}$ by 2.5 to $4 \mu \mathrm{atm}$ and would influence $\mathrm{CO}_{2}$ fluxes by 5 to $8 \%$. On the other hand, changes in nutrient concentrations (phosphate and silicate) have negligible effect on $\mathrm{pCO}_{2}$ computations (doubling the nutrient concentrations from that of climatological values yields a difference in $\mathrm{pCO}_{2}$ by $1 \mu \mathrm{atm})$. Though the present estimates have large error bars, this would nevertheless, give first-hand information on how biogeochemical cycling of carbon is influenced due to climatic events.

\section{Results and discussion}

\subsection{Climatic conditions in the Arabian Sea during 1997-98}

The IOD event of 1997-98 was the strongest climatic event in the 20th century (Saji et al 1999) and the Indian Ocean experienced IOD related warming during this period. Unlike other IOD periods, the Indian Ocean showed an anomalous behavior in 1997-98 at least since 1950. The surface warming occurred during late spring 1997 over the western and a strong surface cooling along the eastern equatorial Indian Ocean (Saji et al 1999). The typical zonal gradient in SST along the equatorial Indian Ocean was completely reversed during this period (Murtugudde et al 1999). The warming in the west peaked in February 1998 that spread across the tropical Indian Ocean (Murtugudde et al 1999).

In order to examine the anomalous climatic conditions in the Arabian Sea during IOD period, I have selected October 1997 as a typical month to represent the period (called henceforth 'IOD period'), and compared the physical and biogeochemical properties in the same month during a normal (when no IOD event occurred) year (i.e., October 1999; called henceforth 'normal period'). The spatial variations in SSTA, CHLA and sea surface height anomaly (SSHA) during IOD and normal periods are plotted in figure $3(\mathrm{a}-\mathrm{f})$. The positive SSTA (warm) $\left(1\right.$ to $\left.1.6^{\circ} \mathrm{C}\right)$ and negative CHLA (low Chl a) ( -0.1 to $0.4 \mathrm{mg} \mathrm{m}^{-3}$ ) are larger especially in the southwestern Arabian Sea during IOD period and found to propagate towards north (figure $3 \mathrm{a}-\mathrm{d}$ ) whereas they are smaller $\left(0\right.$ and $0.4^{\circ} \mathrm{C}$ and 0 to $0.2 \mathrm{mg} \mathrm{m}^{-3}$ ) during normal period (figure $3 \mathrm{~b}, \mathrm{~d}$ ). The magnitude of SSTA and CHLA decreased from south $\left(>1.2^{\circ} \mathrm{C}\right.$ and $\left.<-0.15 \mathrm{mg} \mathrm{m}^{-3}\right)$ to north in the Arabian Sea $\left(0.4^{\circ} \mathrm{C}\right.$ and $-0.1 \mathrm{mg} \mathrm{m}^{-3}$, respectively). Coastal regions displayed relatively larger CHLA (negative) than open sea regions (figure $3 \mathrm{c}, \mathrm{d})$. The southwestern Arabian Sea exhibited negative CHLA and high SSTA during IOD period where cold ASD occurs in normal period due to upwelling of subsurface waters (Prasad et al 

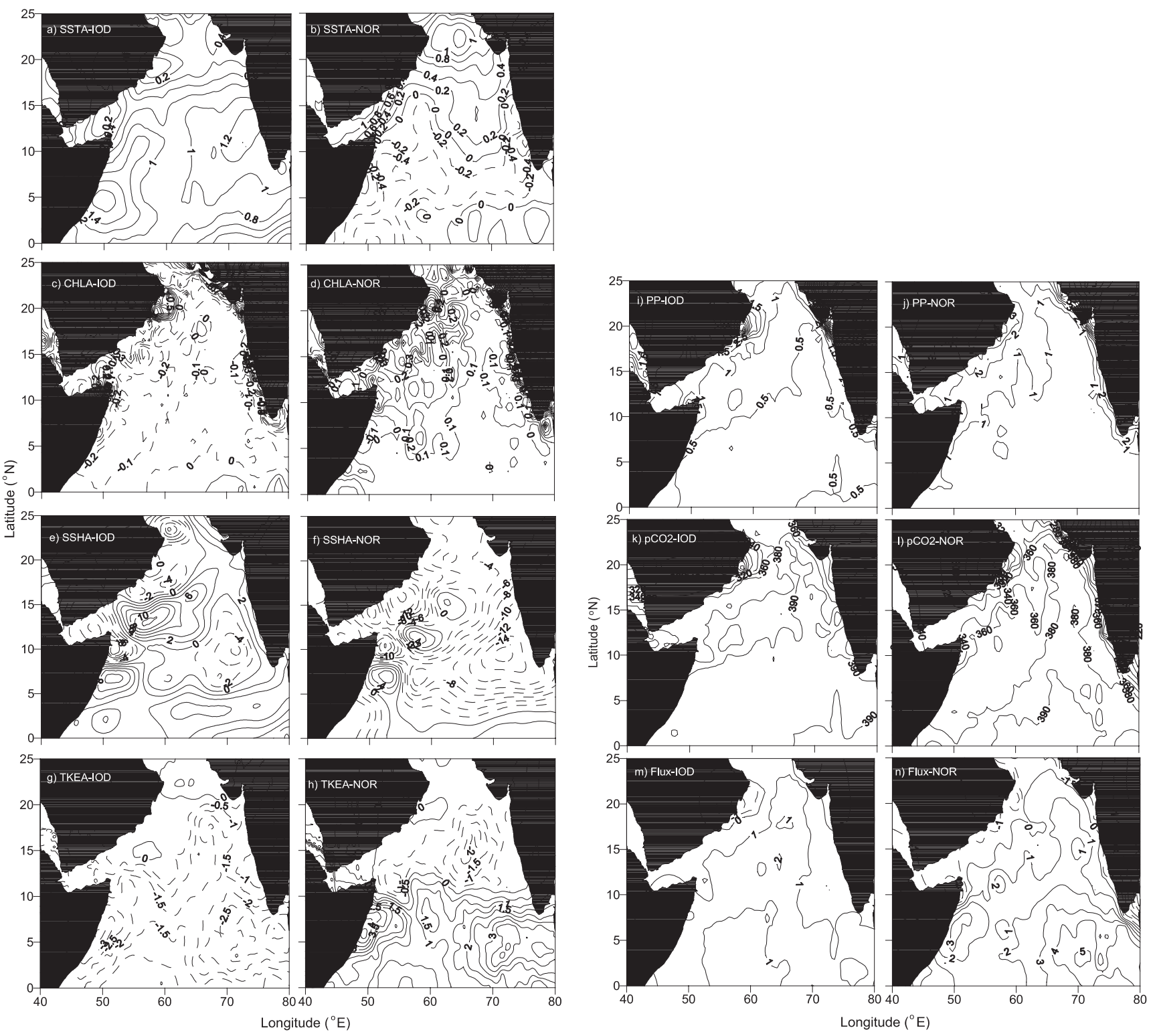

Figure 3. The spatial variations in sea surface temperature anomaly $\left(\mathrm{SSTA} ;{ }^{\circ} \mathrm{C}\right)$, chlorophyll anomaly $\left(\mathrm{CHLA}\right.$ mg $\left.\mathrm{m}^{-3}\right)$, sea surface height anomaly (SSHA; $\mathrm{cm}$ ), turbulent kinetic energy anomaly (TKEA; $\mathrm{m}^{-3} \mathrm{~s}^{-3}$ ), primary production (PP; mmol m$\left.{ }^{-2} \mathrm{~d}^{-1}\right)$, partial pressure of carbon dioxide $\left(\mathrm{pCO}_{2} ; \mu \mathrm{atm}\right)$, and $\mathrm{CO}_{2}$ air-sea fluxes $\left(\mathrm{mmol} \mathrm{m}^{-2} \mathrm{~d}^{-1}\right)$ during IOD (October 1997) and normal periods (October 1999).

2005). The negative SSHA ( -20 to $-140 \mathrm{~mm}$; figure $3 \mathrm{f}$ ) extending across the southern Arabian Sea during normal period is the manifestation of the sea level associated with the cold ASD (Prasad and McClean 2004). On the other hand, SSHA was positive $(>20 \mathrm{~mm})$, except in the southeastern Arabian Sea $(-20$ to $-30 \mathrm{~mm})$, during IOD period due to deepening of thermocline (figure $3 \mathrm{e}$ ). The SSH was shallowed by 30 to $40 \%$ during IOD compared to that of normal period in the southwestern to southcentral Arabian Sea. The change in SSHA drives geostrophic currents anticyclonically in IOD period from cyclonic circulation during normal period in the southern Arabian Sea (Prasad and McClean 2004).
The SSH variations generally reflect thermocline oscillations in the tropics. The positive (negative) SSHA correspond to a deeper (shallow) thermocline. However, the deepening of the thermocline and positive SSTA need not associate with positive SSHA due to asymmetric effect of upwelling on the SSTA (Vinayachandran et al 2002). The upwelled cold water cools the sea surface, but downwelling need not always warm the sea surface (Yu and Reinecker 2000), as a result positive SSTA and SSH need not occur simultaneously. On the other hand, the wind generated turbulent kinetic energy (TKE; $U^{* 3}$ ) is a measure of the ability of wind field to mix the near-surface region of the ocean where $U^{*}=\sqrt{ }(\tau / \rho)$ (see Denman 1973) 

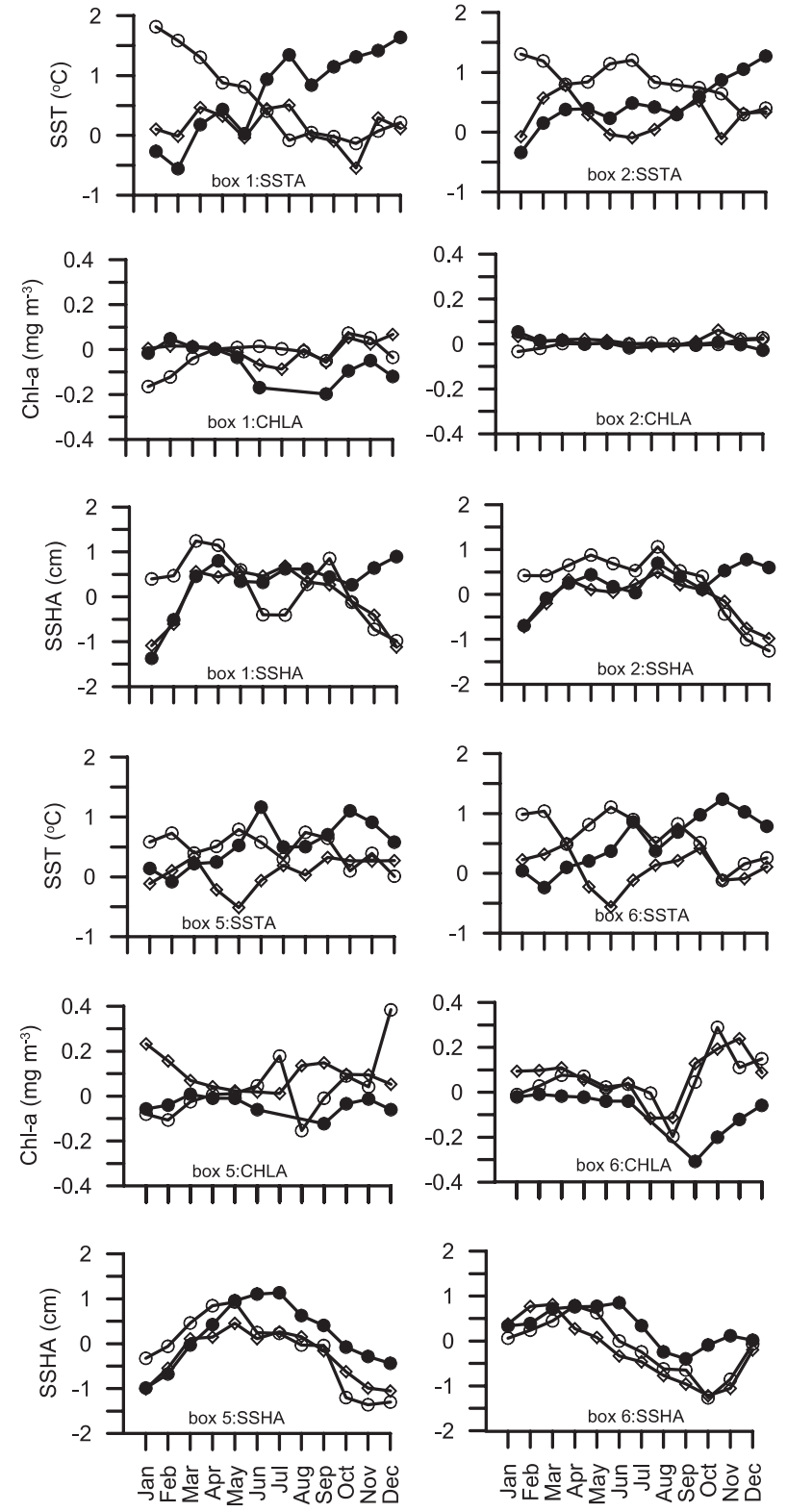
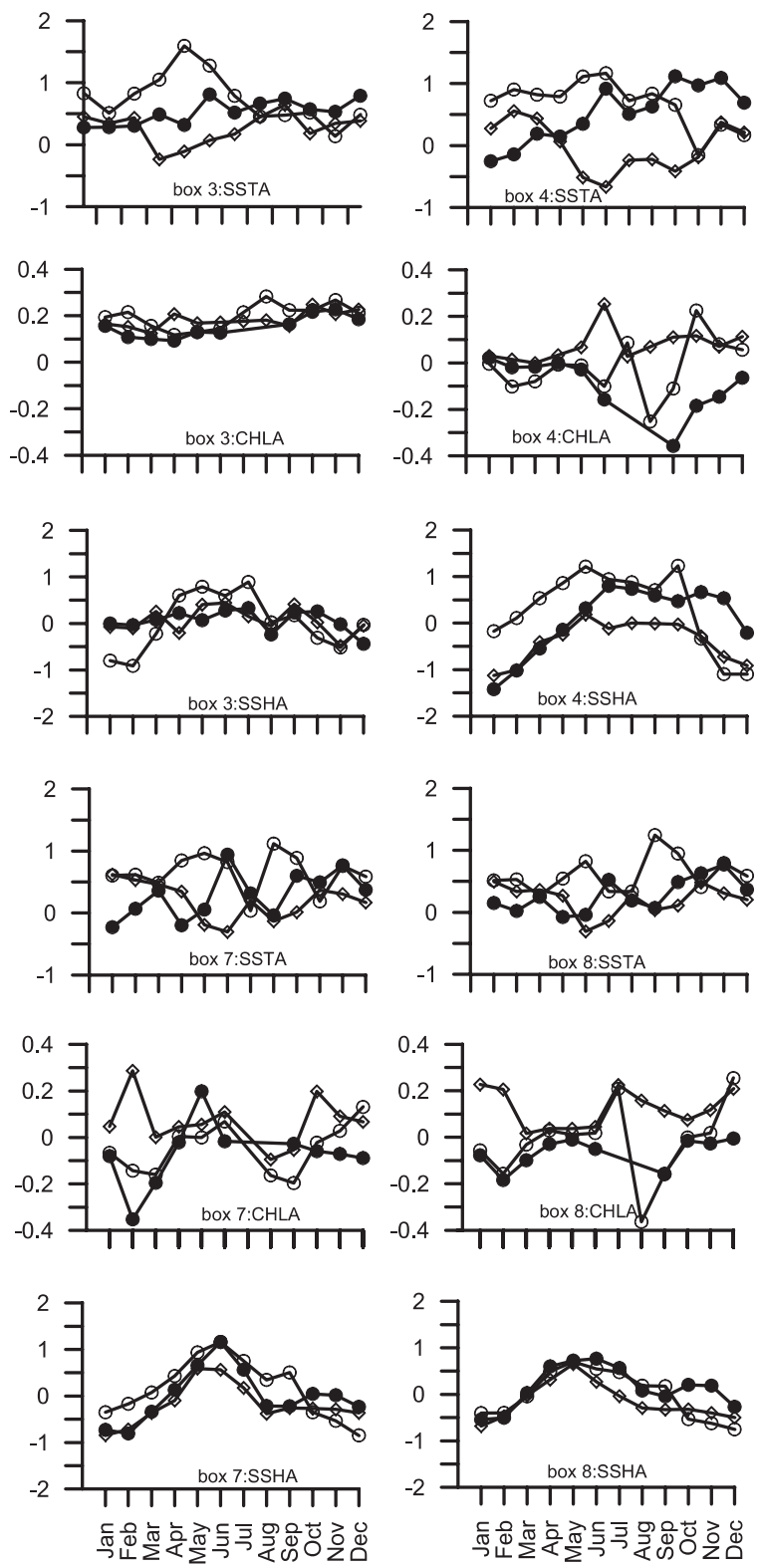

Figure 4. The monthly mean variations in SSTA, CHLA and SSHA during 1997 (closed circles), 1998 (open circles) and 1999 (open diamonds) in different boxes shown in figure 1.

whereas $\tau$ is wind stress and $\rho$ is seawater density. The TKE anomalies (TKEA) are anomalously low during IOD period $\left(0\right.$ to $\left.-3 \mathrm{~m}^{3} \mathrm{~s}^{-3}\right)$ than during normal period $\left(-2\right.$ to $3 \mathrm{~m}^{3} \mathrm{~s}^{-3}$ ) (figure $3 \mathrm{~g}, \mathrm{~h}$ ). Both SSHA and TKEA suggest reduced upward fluxes of nutrients during IOD period due to prevailing downwelling rossby waves (Prasad et al 2005) that led to decreased Chl $a$ concentrations in the southwestern Arabian Sea. The anomalous warming in the Arabian Sea is consistent with the occurrence of anomalously warm SSTs in the western equatorial Indian Ocean during 1997-1998 IOD event (Chambers et al 1999; Murtugudde et al 1999; Yu and Rienecker 1999, 2000; Webster et al 1999; Saji et al 1999). Similarly Vinayachandran and Mathew (2003) observed anomalously deeper thermocline and weak ekman pumping during IOD period in the Bay of Bengal. These authors did not find phytoplankton blooms, caused by open ocean upwelling, during IOD period, as they usually occur during normal period.

In order to examine the influence of IOD event on the spatial variations of properties the entire Arabian Sea is divided into 8 boxes (see figure 1) and the monthly means of SSTA, CHLA, and SSHA in each box are depicted in figure 4. All anomalies showed large spatial variability in the Arabian Sea. The SSTA showed positive anomalies (warm) from June 1997 to May 1998 by 0.1 to $1.8^{\circ} \mathrm{C}$ in the Arabian Sea. The higher magnitude of SSTA was found at the southwestern Arabian Sea (box 1) and decreased towards east 
(box 3) and north. The lowest SSTA was found in the northeastern Arabian Sea (box 8). The central Arabian Sea displayed lower anomalies compared to the coastal regions. The CHLA displayed less spatial variability $\left(0.05-0.4 \mathrm{mg} \mathrm{m}^{-3}\right)$ compared to SSTA. The SSTA are smaller in the northern $\left(<0.6^{\circ} \mathrm{C}\right.$; boxes 7 and 8$)$ than central Arabian Sea $\left(>1{ }^{\circ} \mathrm{C}\right.$; boxes 5 and 6$)$ but, interestingly, CHLA did not show such variations. The low SSTA in the north could possibly be due to cooler SSTs facilitated by strong vertical mixing compared to south (Madhupratap et al 1996a; Prasanna Kumar and Prasad 1996). The peak in SSTA showed large spatial variations. For instance, the SSTA gradually increased from June 1997 to January 1998 and then decreased in boxes 1 and 2 whereas it increased from August to October 1997 and then decreased in boxes 5 and 6 . Therefore, the primary peak in SSTA was observed in December 1997 to January 1998 in boxes 1 and 2, whereas in September to October 1997 in other boxes. The secondary maximum in SSTA was noticed between April and June 1998 in all boxes except in box 1. The secondary peak in SSTA is larger than primary in the coastal regions except in box 1 . The CHLA showed negative correlation with SSTA, i.e., CHLA decreased when SSTA increased $(p \geq 0.001$; figure not shown). However, CHLA and SSTA need not always match as Rao et al (2002) found that despite disappearance of the surface dipole, its signature can be clearly seen in the subsurface due to the large heat capacity of the oceans. This subsurface dipole can also affect surface CHLA through its influence on nutrients entrainment into the mixed layer. The CHLA showed large spatial variability with low in boxes 2 and 3 compared to the other boxes (figure 4). A decrease in CHLA is found between September 1997 and March 1998 in the southern Arabian Sea whereas between September and December 1997 in the northern Arabian Sea. The spatial distribution of SSTA and CHLA suggests that the influence of IOD is not uniform within the Arabian Sea. Three-dimensional models are required to explain the potential reasons for such spatial variability in SSTA and CHLA in the Arabian Sea.

\subsection{Influence of Dipole on primary production}

The biological pump lowers the partial pressure of $\mathrm{CO}_{2}$ in the surface ocean via photosynthesis or primary production, which in turn lowers $\mathrm{CO}_{2}$ in the atmosphere. The Arabian Sea is one of the most productive regions in the World Oceans (Qasim 1982; Bhattathiri et al 1996; Barber et al 2001). The monsoon climate in the Arabian Sea drives a striking semi-annual reversal of surface currents, one of the world's foremost examples of wind-driven ocean circulation (Wyrtki 1973). Intense seasonal variations in primary production were observed in the Arabian Sea (Bhattathiri et al 1996; Banse and English 2000; Barber et al 2001) due to changes in physical forcing. The primary production in the Arabian Sea is mainly controlled by the availability of nutrients. The short-term variability in primary production in the Arabian Sea is mainly caused by changes in physical forcing associated with nutrient injection (Prasanna Kumar et al 2001; Naqvi et al 2002; Wiggert et al 2002). In order to examine how the variations in physical forcing due to climate change, such as IOD, would influence the primary production in the Arabian Sea, the monthly mean photic zone integrated primary production is computed from 1997 to 1999 using equation (8).

\subsubsection{Spatial variations in primary production in the Arabian Sea}

The figure $3(\mathrm{i}, \mathrm{j})$ shows comparison of primary production during IOD (October 1997; figure 3i), and normal periods (October 1999; figure 3j) in the Arabian Sea. The photic zone productivity is higher along the coasts $\left(>1\right.$ mole $\left.\mathrm{C} \mathrm{m}^{-2} \mathrm{~d}^{-1}\right)$ compared to that of the offshore $\left(\sim 0.5\right.$ mole $\left.\mathrm{C} \mathrm{m}^{-2} \mathrm{~d}^{-1}\right)$. The offshore productivity showed large meridional gradients with higher production in the north compared to south. The highest production was found along the Oman coast (> 3.5 mole $\mathrm{C} \mathrm{m}^{-2} \mathrm{~d}^{-1}$ ) during October 1997 due to injection of higher amounts of nutrients via intense coastal upwelling during SW monsoon (June to August; Morrison et al 1998). The highest production rates were also observed close to the northwestern Indian coast, which could be due to injection of nutrients possibly through river runoff by Narmada and Tapti. The offshore production was also higher in the northern Arabian Sea due to injection of nutrients by vertical mixing (Madhupratap et al 1996a; de Sousa et al 1996).

\subsubsection{Comparison of primary production during $I O D$ and normal periods in the Arabian Sea}

The productivity during IOD period (figure $3 \mathrm{i}$ ) is significantly lower than normal period (figure $3 \mathrm{j}$ ) in the entire Arabian Sea. The rate of production decreased during the IOD period because of lower flux of nutrients into the photic zone. The influence on primary production was largely affected in the coastal region, but significant differences were found along the east and west coasts of the Arabian Sea. For instance, primary production along the southwest coast of India decreased by 2 to 4 times during IOD than normal period 
due to reduced upwelling intensity. On the contrary, despite increased SSTA and SSHA along the northwest coast of the Arabian Sea, the differences in the primary production between IOD and normal period were not very high compared to the southwest coast of India (figure $3 \mathrm{i}, \mathrm{j}$ ). It is because the southern portion of the west coast of India is highly influenced by ocean dynamics, such as Kelvin waves and Rossby waves. The early upwelling along the west coast of India is directly related to coastal-trapped Kelvin waves driven by alongshore winds in the Bay of Bengal and equatorial winds (Shankar and Shetye 1997). These equatorial winds are directly influenced by IOD (Rao et al 2002); therefore, significant influence on primary production can be seen during IOD period compared to normal. On the other hand, upwelling along the northwestern Arabian Sea is directly forced by Kelvin waves driven by local along shore winds (Schott and McCreary 2001), therefore, changes in primary production are mainly due to differences in the strength of local winds during IOD and normal periods.

The effect of the physical forcing on nutrient injection is different in the northern and southern Arabian Sea. For instance, winter convective mixing occurs in the northern Arabian Sea, north at $15^{\circ} \mathrm{N}$, which is insignificant in the southern Arabian Sea (Madhupratap et al 1996a). Nevertheless, the highest annual production occurs along the Oman coast due to coastal upwelling (Morrison et al 1998) and in the offshore due to open ocean upwelling and also advected nutrients from the Oman coast in the north of $15^{\circ} \mathrm{N}$ during SW monsoon (Manghnani et al 1998; Prasanna Kumar et al 2001). Since the study period, September 1997 to April 1998, falls within the monsoon period, the study region is divided into northern and southern Arabian Sea with the boundary of $15^{\circ} \mathrm{N}$. Figure 5(a, b) shows monthly-integrated production in the northern and southern Arabian Sea during IOD and normal period. The photic zone production is always higher during normal compared to IOD period in the entire Arabian Sea. The decrease in productivity was largest during September 1997 (37\%) and lowest (15\%) during April 1998 than normal period (1999) in the southern Arabian Sea. On the other hand, the difference in production between IOD and normal period is relatively smaller in the northern compared to southern Arabian Sea. This could be mainly due to less influence of IOD on Oman upwelling as it is directly forced by Kelvin waves driven by local along shore winds (Schott and McCreary 2001). However, consistently lower production was observed compared to normal period that could possibly be due to less intense mixing during monsoon in IOD period. The highest difference in primary production occurred during February 1998 whereas the difference is almost negligible during April 1998 in the northern Arabian Sea (figure 5b). The time-integrated production over IOD period (September 1997 to April 1998) and normal period suggests that 32 and $26 \%$ of primary production was reduced in the southern and northern Arabian Sea respectively during IOD than normal period. This suggests that IOD events have strong influence on photic zone production possibly through deepening of nutricline. However, this may be treated as the lower limit, as this estimate does not include the effect during June to August 1997, when peak in production generally occurs (Bhattathiri et al 1996; Barber et al 2001), due to lack of ocean color data.

\subsection{Influence of Dipole on surface $p \mathrm{CO}_{2}$ and its fluxes at the air-sea interface}

The Arabian Sea is a perennial source of $\mathrm{CO}_{2}$ to the atmosphere (Somasundar et al 1990; George et al 1994; Kortzinger et al 1997; Goyet et al 1998; Sarma et al 1996, 1998; Sabine et al 2000; Takahashi et al 2002; Sarma 2003) with strong seasonal and spatial variability in the direction of fluxes. The high surface $\mathrm{pCO}_{2}$ in the Arabian Sea is controlled by the strength of the vertical mixing during winter (December to February) and upwelling during summer (June to August) and depth of thermocline (Sarma et al 2000). The $\mathrm{pCO}_{2}$ levels increase sharply in the thermocline such that both depths from where upwelling or convective mixing occurs, and the position of the thermocline are critical controls of surface water $\mathrm{pCO}_{2}$ (Sarma et al 1996, 2000). In addition to this, biological uptake, gas exchange and temperature will modify the surface water $\mathrm{pCO}_{2}$. Increase in temperature will cause $\mathrm{pCO}_{2}$ to increase, due to decrease in solubility, while biological production and gas transfer result in its decrease.

The IOD has a strong influence on the surface $\mathrm{pCO}_{2}$ levels by affecting the three main processes controlling $\mathrm{pCO}_{2}$ distribution in the Arabian Sea. They are the depth of the thermocline, increase in SST, and strength of the winds. The reduced winds during IOD period decrease mixing rates, as evidenced by SSHA (figure 3e) and TKEA (figure 3g), and also fluxes of $\mathrm{CO}_{2}$ at the air-water interface. Deepening of the thermocline further reduces the surface $\mathrm{pCO}_{2}$ levels by inhibiting mixing of $\mathrm{pCO}_{2}$ rich subsurface waters with surface. Increase in SST reduces solubility of $\mathrm{CO}_{2}$ in the seawater (Weiss 1974). Further computations were made to examine how these processes influence surface $\mathrm{pCO}_{2}$ levels and exchange of $\mathrm{CO}_{2}$ with atmosphere during IOD and normal periods. 

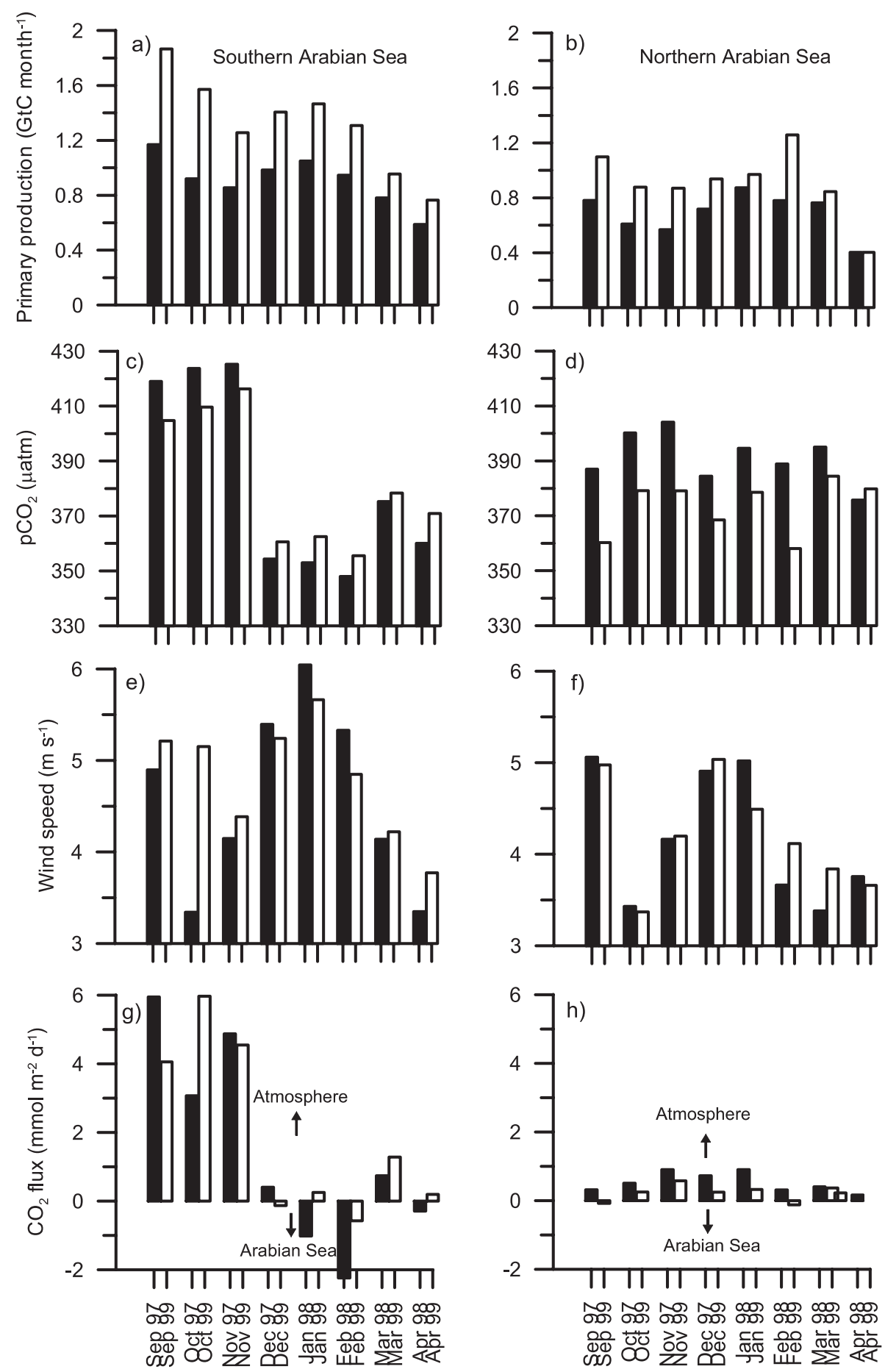

Figure 5. Average (a) primary production (c) $\mathrm{pCO}_{2}$, (e) wind speeds and (g) $\mathrm{CO}_{2}$ air-sea fluxes in the southern Arabian Sea, and (b), (d), (f) and (h) respectively in the northern Arabian Sea. Positive fluxes are from sea to atmosphere and negative fluxes are from atmosphere to sea.

\subsubsection{Spatial distribution of surface $\mathrm{pCO}_{2}$ in the Arabian Sea}

The basin-scale distribution of surface $\mathrm{pCO}_{2}$ in the Arabian Sea is shown in figure $3(\mathrm{k}, \mathrm{l})$ during IOD and normal periods. The surface $\mathrm{pCO}_{2}$ levels ranged between 360 and $400 \mu \mathrm{atm}$ in IOD period in the Arabian Sea with large spatial variability.
The $\mathrm{pCO}_{2}$ levels along the Oman coast were $<370 \mu$ atm due to increased biological activity following the upwelling during SW monsoon. The $\mathrm{pCO}_{2}$ levels in the open sea region show higher levels in the south compared to the north. This is mainly caused by high primary production, in the north during post monsoon season, fueled by higher amounts of nutrients injected by upwelling 
and that advected from the coastal regions to the offshore during SW monsoon (Morrison et al 1998; Prasanna Kumar et al 2001). At the end of the post-monsoon, production decreases due to nonavailability of nutrients in the north (Banse and English 2000; Barber et al 2001) thereby increasing the $\mathrm{pCO}_{2}$ levels. Higher $\mathrm{pCO}_{2}$ levels in the north compared to the south resulted from the occurrence of intense winter convective mixing in the north (north of $15^{\circ} \mathrm{N}$ ) through the injection of $\mathrm{pCO}_{2}$ rich subsurface waters to the surface (Madhupratap et al 1996a; Sarma et al 1996).

\subsubsection{Comparison of surface $\mathrm{pCO}_{2}$ levels during IOD and normal periods in the Arabian Sea}

Figure $3(\mathrm{k}, \mathrm{l})$ compares surface $\mathrm{pCO}_{2}$ levels during IOD and normal periods (for October month) in the Arabian Sea. The $\mathrm{pCO}_{2}$ levels were relatively higher (by $<10-20 \mu \mathrm{atm}$ ) during IOD than normal period. Especially these differences are large in the northern Arabian Sea compared to the south. The southwestern Arabian Sea, where ASD was found during normal period, exhibited relatively higher $\mathrm{pCO}_{2}$ levels during IOD period compared to the normal period by 10 to $20 \mu \mathrm{atm}$. Despite decrease in the vertical mixing during IOD period, as shown by the shallower SSHA (figure 3e, f) and lower TKEA (figure $3 \mathrm{~g}, \mathrm{~h}$ ), higher $\mathrm{pCO}_{2}$ levels could have been due to decrease in solubility of $\mathrm{CO}_{2}$ and primary production (figure $3 \mathrm{i}, \mathrm{j}$ ).

In order to examine the spatial variability in the difference in $\mathrm{pCO}_{2}$ levels between IOD and normal period, the entire Arabian Sea is divided into northern and southern Arabian Sea with a hypothetical boundary at $15^{\circ} \mathrm{N}$. The average $\mathrm{pCO}_{2}$ levels, and wind speeds during IOD and normal periods are given in figure $5(\mathrm{c}-\mathrm{f})$. The differences in $\mathrm{pCO}_{2}$ levels between IOD and normal periods varied from 3 to $15 \mu \mathrm{atm}$ in the southern Arabian Sea during entire IOD period (September 1997 to April 1998) while they ranged between 10 and $30 \mu \mathrm{atm}$ in the northern Arabian Sea. Large differences are found especially during September and February but not in April. These differences arise from changes in controlling factors, i.e., physical and biological processes.

\subsubsection{Controlling processes on surface $\mathrm{pCO}_{2}$}

As described by Prasad and McClean (2004) reduced vertical mixing leads to warmer SSTs during IOD period. This would affect $\mathrm{pCO}_{2}$ levels in three ways. They are:

- reduction in vertical mixing decreases contribution of $\mathrm{pCO}_{2}$ through mixing from the base of the mixed layer,
- the temperature dependence of the solubility of $\mathrm{CO}_{2}$, which decrease with increase in SST (Weiss 1974; Fushimi 1987; Inoue et al 1987) and

- enhanced bacterial respiration rates with SST that increase in $\mathrm{pCO}_{2}$ levels (Ducklow 1993).

In addition to this, Chl a concentrations also decreased (figure 3c, d), which generally lower $\mathrm{pCO}_{2}$ levels through primary production. Louanchi et al (1996) studied the effect of different processes on surface $\mathrm{pCO}_{2}$ levels in the Indian Ocean using one-dimensional model and found that the magnitude of increase in $\mathrm{pCO}_{2}$ by mixing is almost equal to the decrease in $\mathrm{pCO}_{2}$ by biological uptake and fluxes to the atmosphere in the Arabian Sea. Therefore, the net effect on $\mathrm{pCO}_{2}$ levels depends mainly on dominant processes among these. The less $\mathrm{pCO}_{2}$ differences between IOD and normal periods suggest that these processes might cancel out one another, thus fewer variations are found in the surface $\mathrm{pCO}_{2}$. Though changes in salinity are unknown during IOD and normal period in the Arabian Sea, Jabaud-Jan et al (2004) did not observe any significant variations in salinity during 1998 and 2000 in the southern Indian Ocean. Therefore, the total alkalinity might not have varied significantly during IOD and normal periods and hence variations in $\mathrm{pCO}_{2}$ are mainly controlled by changes in SST and DIC wherein the latter is a function of SST and Chl $a$. The changing contribution of temperature and biological processes can be deduced by calculating the difference in DIC, and then $\mathrm{pCO}_{2}$, in two scenarios, i.e., the difference in SST and Chl $a$ between IOD and normal periods.

Figure 6 shows the effect of temperature and biological processes on surface $\mathrm{pCO}_{2}$ in the northern and southern Arabian Sea during IOD period. The net effect of decrease in vertical mixing and solubility decrease with increase in SST is an increase in $\mathrm{pCO}_{2}$ levels by $2 \mu$ atm from September to November 1997 but a decrease by 10-22 $\mu$ atm from December 1997 to March 1998 in the southern Arabian Sea. On the other hand, a decrease in Chl $a$ increases $\mathrm{pCO}_{2}$ by 7 to $23 \mu$ atm during IOD period in the southern Arabian Sea. The effect of temperature and biology are in the opposite directions, the net effect on change in $\mathrm{pCO}_{2}$ is -5 to $14 \mu \mathrm{atm}$ in the southern Arabian Sea during IOD period. On the other hand, changes in SST and Chl $a$ lead to increases in $\mathrm{pCO}_{2}$ by 0.3 to 3.3 and 4.3 to $25.1 \mu \mathrm{atm}$ in the northern Arabian Sea, respectively. This suggests that $\mathrm{pCO}_{2}$ changes due to temperature are canceled out to some extent by biological effect in the southern Arabian Sea whereas higher $\mathrm{pCO}_{2}$ levels in the northern Arabian Sea mainly resulted from the decrease in primary production. 

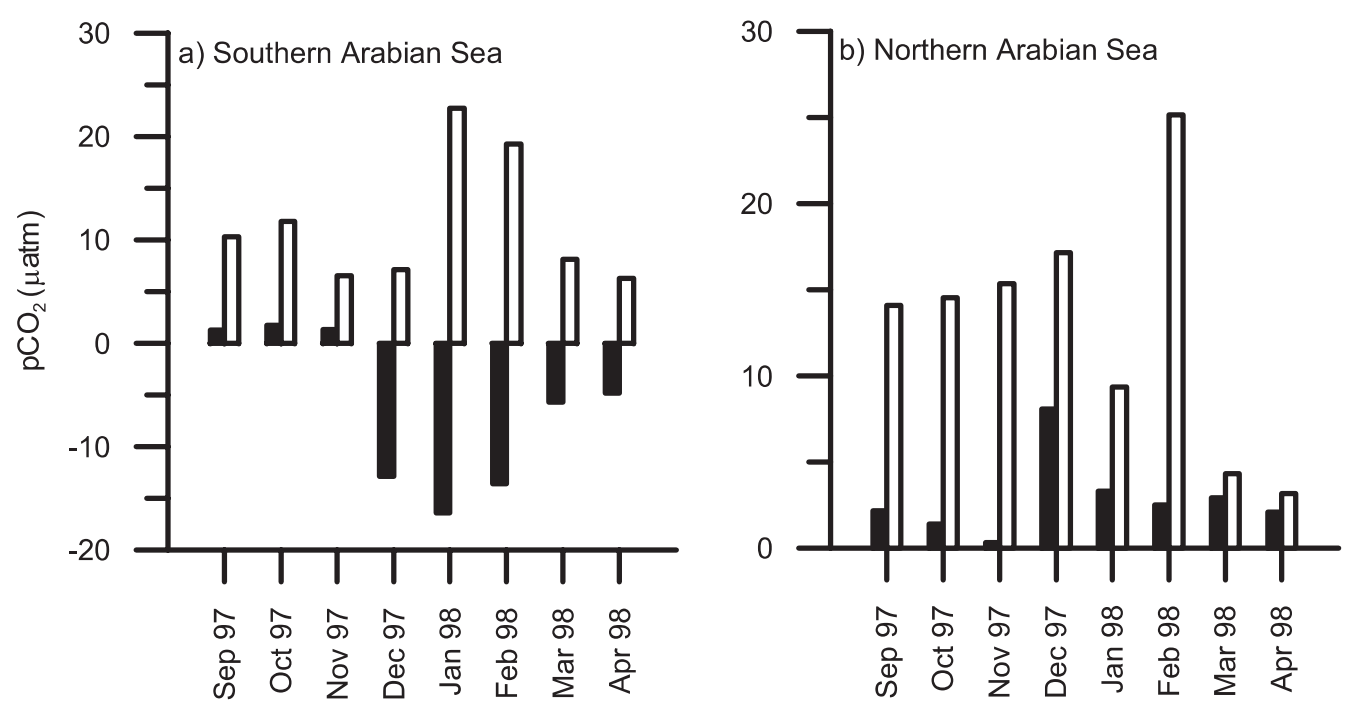

Figure 6. Influence of SST (open bars) and Chl a (closed bars) on surface $\mathrm{pCO}_{2}$ in the (a) southern Arabian Sea and (b) northern Indian Ocean during IOD period.
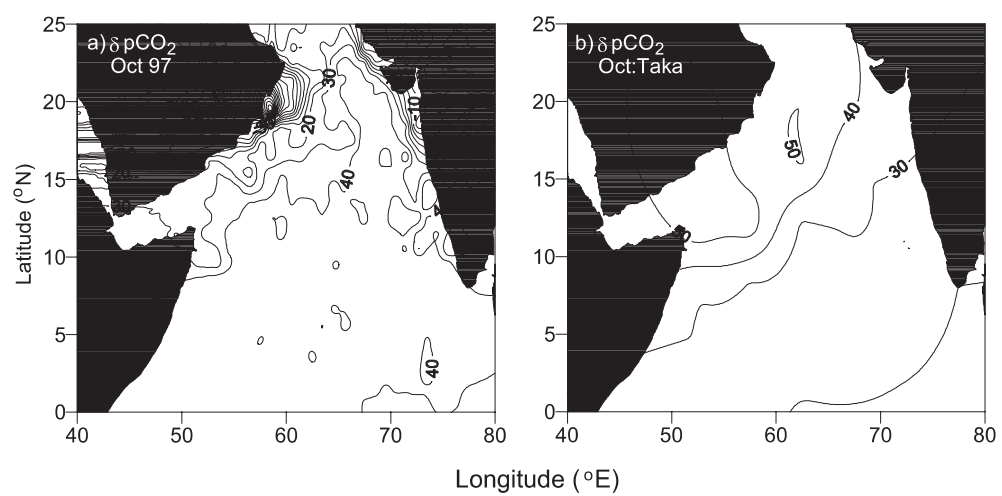

Figure 7. Spatial variations in $\delta \mathrm{pCO}_{2}\left(=\mathrm{pCO}_{2 \text { water }}-\mathrm{pCO}_{2 \text { air }}\right)$ during (a) October 1997 and (b) climatology in October (Takahashi et al 2002).

Figure 7 compares $\delta \mathrm{pCO}_{2}$ (seawater $\mathrm{pCO}_{2}$ minus atmospheric $\mathrm{pCO}_{2}$ ) of October 97 with that of Takahashi Climatology in October (Takahashi et al 2002; http://ingrid.ldeo.columbia.edu/ SOURCES/ .LDEO/ .Takahashi/ .dp90/ sea-air/ .pCO2/). The $\delta \mathrm{pCO}_{2}$ levels were significantly higher during October 97 by 2 to $49 \mu \mathrm{atm}$ (mean $37 \mu \mathrm{atm})$ from that of climatological values suggesting significant $\mathrm{pCO}_{2}$ increase during IOD period in the Arabian Sea. Jabaud-Jan et al (2004) found that $\mathrm{pCO}_{2}$ levels were higher by 10 to $45 \mu \mathrm{atm}$ in the southern subtropical Indian Ocean (30-40S) during January 1998 than 2000. Relatively higher $\mathrm{pCO}_{2}$ levels in the southwestern Indian Ocean during IOD period have mainly resulted from increase in temperature; since Chl $a$ levels are always low in the subtropical Indian Ocean due to very low nutrient concentrations. On the other hand, Jabaud-Jan et al (2004) found no significant changes in surface $\mathrm{pCO}_{2}$ levels between the years 1998 and 2000, in the Sub-Antarctic Zone of the Indian Ocean despite the warmer SST (by $1^{\circ} \mathrm{C}$ ) during 1998 . They attributed this to competing effects of thermodynamical and biological processes that occur in different directions. Recently Baker et al (2006) compared 13 transport models to examine interannual variability in regional $\mathrm{CO}_{2}$ fluxes from 1988 to 2003 and found significant increase in $\mathrm{CO}_{2}$ fluxes during 1997-98 from the tropical Indian Ocean. The present study suggests that the primary productivity is a key process to explain the variability in $\mathrm{pCO}_{2}$ and its fluxes in the Arabian Sea. The magnitude of increased $\mathrm{pCO}_{2}$ levels is large in the subtropical Indian Ocean than in the Arabian Sea as the core of IOD situated to the south of the equator (Saji et al 1999). However, the controlling factors are different such as, dominant thermal effect in the former but greater biological influence in the latter region. 


\subsubsection{Sea-air $\mathrm{CO}_{2}$ fluxes in the Arabian Sea}

The net flux of $\mathrm{CO}_{2}$ across the sea-air interface is the product of transfer velocity, $k$, the solubility of $\mathrm{CO}_{2}, s$, and the $\mathrm{pCO}_{2}$ difference between the ocean and atmosphere according to the equation (6). Using monthly mean $\mathrm{pCO}_{2}$ and wind speeds, $\mathrm{CO}_{2}$ fluxes are calculated and presented in figure $3(\mathrm{~m}, \mathrm{n})$ during IOD and normal periods. No correlation is seen between distribution of $\mathrm{pCO}_{2}$ (figure $3 \mathrm{k}, \mathrm{l}$ ) and its fluxes (figure $3 \mathrm{~m}, \mathrm{n}$ ) during both the periods, as higher $\mathrm{pCO}_{2}$ levels can be seen during IOD period (figure 3k) whereas fluxes are higher, especially in southern Arabian Sea, during normal period (figure $3 \mathrm{n}$ ). This is due to differences in wind speeds. The basin scale average wind speeds in the northern and southern Arabian Sea are depicted in figure $5(\mathrm{e}, \mathrm{f})$. Significant differences in wind speeds were observed in both regions, especially in October and, January to March, during IOD and normal periods. During both IOD and normal periods, the Arabian Sea is acting mostly as a source of $\mathrm{CO}_{2}$ to the atmosphere, except during January and February, in the southern Arabian Sea. The average basin scale fluxes to the atmosphere varied between IOD period $(-2.1$ to $3.1 \mathrm{mmol} \mathrm{m}^{-2} \mathrm{~d}^{-1} ;$ mean $\left.0.78 \mathrm{mmol} \mathrm{m}^{-2} \mathrm{~d}^{-1}\right)$ and normal period $\left(-0.3\right.$ to $3.1 \mathrm{mmol} \mathrm{m}^{-2} \mathrm{~d}^{-1}$; mean $\left.1.15 \mathrm{mmol} \mathrm{m}^{-2} \mathrm{~d}^{-1}\right)$ in the southern Arabian Sea whereas they varied during IOD (0.6 to $1.8 \mathrm{mmol} \mathrm{m}^{-2} \mathrm{~d}^{-1}$; mean $\left.1.16 \mathrm{mmol} \mathrm{m}^{-2} \mathrm{~d}^{-1}\right)$ and normal periods $\left(-0.2\right.$ to $1.1 \mathrm{mmol} \mathrm{m}^{-2} \mathrm{~d}^{-1}$; mean $\left.0.45 \mathrm{mmol} \mathrm{m}^{-2} \mathrm{~d}^{-1}\right)$ in the northern Arabian Sea. During the entire IOD period, the northern Arabian Sea acts as a source of $\mathrm{CO}_{2}$ to the atmosphere due to decrease in primary production (figure $5 \mathrm{~g}, \mathrm{~h}$ ). The fluxes to the atmosphere decreased during IOD period $\left(11.5 \mathrm{TgC}^{-1}\right)$ than normal period $\left(15.6 \mathrm{TgC}^{-1}\right)$ in the southern Arabian Sea whereas fluxes increased during IOD period $\left(4.2 \mathrm{TgCy}^{-1}\right)$ compared to the normal period $\left(1.8 \mathrm{TgCy}^{-1}\right)$ in the northern Arabian Sea. Especially lower fluxes were found during IOD period during January 1997 to March 1998 in the southern Arabian Sea, which acts as a strong sink for atmospheric $\mathrm{CO}_{2}$ compared to normal period due to reduced vertical mixing. The fluxes in the entire basin decreased by $10 \%$ during IOD $\left(15.7 \mathrm{TgC}^{-1}\right)$ than normal period $\left(17.4 \mathrm{TgC}^{-1}\right)$. Despite higher $\mathrm{pCO}_{2}$ levels found during IOD period, lower fluxes were mainly driven by weaker winds. Nevertheless, the changes in amount of $\mathrm{CO}_{2}$ fluxes to atmosphere are smaller than that of south Indian Ocean as the subtropical Indian Ocean acted as a source of $\mathrm{CO}_{2}$ to the atmosphere $\left(2 \mathrm{mmol} \mathrm{m}^{-2} \mathrm{~d}^{-1}\right)$ in January 1998 whereas it is a sink of $-1 \mathrm{mmolm}^{-2} \mathrm{~d}^{-1}$ in January 2000 (Jabaud-Jan et al 2004).

The changes in $\mathrm{CO}_{2}$ fluxes during IOD and normal periods have some similarities and discrepancies with those in the equatorial Pacific Ocean where El Niño reduces equatorial upwelling and deepens thermocline. During normal period, upwelling in the equatorial belt of Pacific Ocean supplies annually 800 to $1000 \mathrm{TgCy}^{-1}$ as $\mathrm{CO}_{2}$ to the atmosphere with most of the release occurring in the eastern region (Feely et al 1997, 1999, 2002; Takahashi et al 2002). The large area of the eastern equatorial Pacific affected by the upwelling makes this region a significant oceanic source of $\mathrm{CO}_{2}$ to the atmosphere. During El Niño period, thermocline deepens and upwelling intensity decreases, resulting in warm SSTA of as high as $5^{\circ} \mathrm{C}$. Feely et al (2002) observed that $\mathrm{CO}_{2}$ fluxes decreased by 60 to $75 \%$ during El Niño period (200 to $400 \mathrm{TgCy}^{-1}$ ) than normal period (800 to $1000 \mathrm{PgC}^{-1}$ ) when $\mathrm{pCO}_{2}$ levels were lower by 20-50 $\mu \mathrm{atm}$ during the former than latter period. Therefore, the decrease in fluxes was mainly caused by decrease in $\mathrm{pCO}_{2}$ and wind speeds during $\mathrm{El}$ Niño period. Although major nutrient concentrations are above the saturation levels, the decrease in phytoplankton productivity by $50 \%$ during $\mathrm{El}$ Niño period has been caused by iron deficiency in the equatorial Pacific (Chavez et al 1999).

Unlike in the equatorial Pacific, the $\mathrm{pCO}_{2}$ levels increased during IOD period in the Arabian Sea as well as subtropical Indian Ocean (JabaudJan et al 2004) than normal period. The magnitude of $\mathrm{pCO}_{2}$ increase is relatively smaller in the Arabian Sea due to less influence of IOD in the Arabian Sea than subtropical Indian Ocean. Despite higher $\mathrm{pCO}_{2}$ levels in the Arabian Sea, the lower fluxes during IOD period were a result of weaker winds whereas $\mathrm{CO}_{2}$ fluxes increased by 2 to 3 times in the subtropical Indian Ocean during IOD period (Jabaud-Jan et al 2004). In addition to this, the balance between decrease in $\mathrm{pCO}_{2}$ due to reduced vertical mixing and uptake by primary producer reduced $\mathrm{pCO}_{2}$ difference between IOD and normal periods in the southern Arabian Sea. On the contrary, changes in both SST and primary production enhanced $\mathrm{pCO}_{2}$ levels in the northern Arabian Sea leads to the emission of $\mathrm{CO}_{2}$ to the atmosphere by about 2.5 times higher than normal period. On the basin scale, the $\mathrm{CO}_{2}$ efflux to atmosphere decreased by $10 \pm 1 \%$ whereas primary production decreased by $\sim 30 \%$, the latter caused by unavailability of new nitrogen due to reduced vertical mixing. Though these two processes lower $\mathrm{pCO}_{2}$ levels, increase in 
SST elevates $\mathrm{pCO}_{2}$ thermodynamically and also through enhanced bacterial respiration.

\section{Summary and conclusions}

The Arabian Sea (northwestern Indian Ocean) experienced IOD related warming during 1997-98 resulting in increase in surface temperatures up to $1.8^{\circ} \mathrm{C}$ and decrease in $\mathrm{Chl} a$ concentrations by $0.5 \mathrm{mg} \mathrm{m}^{-3}$ from that of normal period. SSHA and TKEA suggest that reduced vertical mixing during IOD period might lead to deepening of thermocline and nutricline in the Arabian Sea. As a result, supply of nutrients to the photic zone was reduced during IOD period leading to a decrease in primary production by $\sim 30 \%$ compared to that in normal period. On the contrary, surface $\mathrm{pCO}_{2}$ levels increased by 5 to $20 \mu$ atm during IOD period but fluxes of $\mathrm{CO}_{2}$ to the atmosphere decreased by $10 \%$ due to prevailing weaker winds during IOD than normal period. The primary production is a key controlling process to explain the variability in the $\mathrm{pCO}_{2}$ levels and air-sea fluxes in the Arabian Sea during IOD period. Due to less supply of nitrate from the deeper layers, the new production is expected to decrease thereby primary production might have been supported by regenerated nutrients. Such conditions favor picoplankton blooms. The phytoplankton composition in the Arabian Sea suggested that small phytoplankton (picoplankton $<2 \mu \mathrm{m}$ ) are abundant during oligotrophic seasons when regenerated nutrients fuel the primary production (Campbell et al 1998; Liu et al 1998). It is because the size of phytoplankton produced is of a significant biogeochemical importance. Larger phytoplankton $(>2 \mu \mathrm{m}$ such as diatoms, dinoflagellates, etc.) results in the formation of bigger particulate organic carbon, facilitating the export of phytogenic carbon to the deep sea. On the other hand, picoplankton produces dissolved organic matter that is transported laterally or gets respired in the photic zone itself thereby increasing the surface $\mathrm{pCO}_{2}$ levels. For instance, during El Niño period, the new production in the equatorial Pacific Ocean is reduced by $>50 \%$, where about 87 to $90 \%$ of the nitrogen demand was met by the regeneration of organic carbon (McCarthy et al 1996). The export production also decreased by about $30 \%$, and accounted to only $2 \%$ of primary production whereas $\sim 15 \%$ of production was transported laterally in the form of dissolved organic matter (Najjar et al 1992; Bacon et al 1996) in the equatorial Pacific. Though the reduction in primary production is very significant $(\sim 30 \%)$ compared to air-sea $\mathrm{CO}_{2}$ fluxes (10\%) in the Arabian Sea, it is important to know how much of export production was changed due to
IOD as this region exports almost double to that of flux to the atmosphere (Sarma 2004). The decrease in export production will have great impact in the entire water column. Sarma (2002) found that the intensity of oxygen minimum zone (OMZ) in the Arabian Sea is controlled by both physical pump and biological remineralization of organic matter. Therefore, decrease in primary production in the photic zone reduces export production with implications to biogeochemistry of subsurface and deeper water column, that include abundance of biota, intensity of oxygen minimum zone and nitrous oxide production, etc. However, the evaluation of such an impact requires in situ time-series observations.

Madhupratap et al (1996b) observed lack of seasonality in the microzooplankton abundance in the Arabian Sea due to existence of microbial loop. Microzooplankton feed upon phytoplankton during monsoon whereas upon bacteria during nonmonsoon seasons when phytoplankton production is low. Bacterial abundance is at its peak during non-monsoon season when they utilize left over organic carbon during monsoon seasons. Significant decrease in the primary production due to climatic events, such as IOD, would influence entire ecosystem structure from bacteria to fish. Examining such changes require long-term time-series observations. In addition to this, though the $\mathrm{CO}_{2}$ fluxes are not significantly increased during IOD period in the Arabian Sea, accumulation of higher $\mathrm{pCO}_{2}$ in the surface waters is observed. Heat content in the ocean is increasing due to increase of greenhouse gases (Levitus et al 2000, 2001). Therefore, enhanced carbon dioxide emissions into the atmosphere are expected to increase the SSTs by several degrees in the next century. Although the warm anomaly observed in the IOD period in the Arabian Sea represents an episodic event on a decadal scale, monitoring the effect of such dramatic changes on biogeochemical properties would help us to understand future oceanic $\mathrm{pCO}_{2}$ distribution and air-sea flux of $\mathrm{CO}_{2}$ in a warmer climate.

\section{Acknowledgements}

This work would not have been possible without the considerable efforts of the scientists during Indian, German, Netherlands, UK, US-JGOFS and WOCE Studies expeditions. I thank all the scientists for making available their high quality data sets to the public. I also appreciate SeaWiFS, AVHRR, JPL (NASA) for making available satellite SST, Chl $a$, wind speeds and SSH data sets. I would like to thank three anonymous reviewers for their constructive criticism that improved the previous versions of the manuscript. 


\section{References}

Bacon M P, Cochran J K, Hirschberg D, Hammar T R and Fleer A P 1996 Export flux of carbon at the equator during the EqPac time-series cruises estimated from 234th measurements; Deep-Sea Res. II 43 1133-1153.

Baker D F, Law R M, Gurney K R, Rayner P, Peylin P, Denning A S, Bousquet $\mathrm{P}$, Bruhwiler L, Chen Y H, Ciais P, Fung I Y, Heimann M, John J, Maki T, Maksyutov S, Massrie K, Prather M, Pak B, Taguchi S and Zhu Z 2006 TransCom 3 inversion intercomparison: Impact of transport model errors on the interannual variability of regional $\mathrm{CO}_{2}$ fluxes, 1988-2003; Global Biogeochem. Cycles 20 doi:10.1029/2004GB 002439.

Banse K and English D C 2000 Geographical differences in seasonality of CZCS-derived phytoplankton pigment in the Arabian Sea for 1978-1986; Deep-Sea Res. II 47 1623-1677.

Barber R T, Marra J, Bidigare R C, Codispoti L A, Halpern D, Johnson Z, Latasa M, Goericke R and Smith S L 2001 Primary productivity and its regulation in the Arabian Sea during 1995; Deep-Sea Res. II 48 $1127-1172$

Bates N 2001 Interannual variability of oceanic $\mathrm{CO}_{2}$ and biogeochemical properties in the Western North Atlantic subtropical gyre; Deep-Sea Res. II 48 1507-1528.

Behera S K, Krishnan S and Yamagata T 1999 Unusual ocean-atmosphere conditions in the tropical Indian Ocean during 1994; Geophys. Res. Lett. 26 3001-3004.

Behera S K, Salvekar P S and Yamagata T 2000 Simulation of interannual SST variability in the tropical Indian Ocean; J. Climate 13 3487-3489.

Bhattathiri P M A, Pant A, Sawant S, Gauns M, Matondkar S G P and Mohanraju R 1996 Phytoplankton production and chlorophyll distribution in the eastern and central Arabian Sea in 1994-1995; Curr. Sci. 71 857-862.

Buesseler K O, Ball L, Andrews J, Beniteznelson C, Belastock R, Chai F and Chao Y 1998 Upper ocean export of particulate organic carbon in the Arabian Sea derived from thorium-234; Deep-Sea Res. II $\mathbf{4 5}$ 2461-2488.

Campbell L, Landry M R, Constantinou J, Nolla H A, Brown S L, Liu H and Caron D A 1998 Response of microbial community structure to environmental forcing in the Arabian Sea; Deep-Sea Res. II 45 2301-2326.

Chambers D P, Tapley B D and Stewart R H 1999 Anomalous warming in the Indian Ocean coincident with El Niño; J. Geophys. Res. 104 3035-3047.

Chavez F P, Buck K R, Service S K, Newton J and Barber R T 1996 Phytoplankton variability in the central and eastern tropical Pacific; Deep-Sea Res. II 43 835-870.

Chavez F P, Strutton P G, Friederich G E, Feely R A, Wanninkhof R, Feldman G, Foley D and McPhaden M J 1999 Biological and chemical response of the equatorial Pacific Ocean to climatic forcing during the 1997-1998 El Niño; Science 286 2126-2131.

Conkright $\mathrm{M}$ E, Levitus S, O'Brien $\mathrm{T}$, Boyer $\mathrm{T}$ P, Stephens C, Johnson T, Statoplos L, Baranova O, Antonov J, Gelfled R, Burney J, Rochester J and Forgy C 1998 World Ocean database, 1998. US Department of Commerce. National Oceanic and Atmospheric Administration, Washington DC, 114pp.

de Sousa S N, Kumar M D, Sardessai S, Sarma V V S S and Shirodkar P V 1996 Seasonal variability in oxygen and nutrients in the central and eastern Arabian Sea; Curr. Sci. 71 847-851.

Denman K L 1973 A time-dependent model of the upper ocean; J. Phys. Oceanogr. 3 185-196.
Dore J E, Carrillo C J, Hebel D V and Karl D M 2000 Carbon cycle observations at the Hawaii Ocean Time Series Station ALOHA; In: Proceedings of the PICES North Pacific $\mathrm{CO}_{2}$ data synthesis symposium (eds) Nojiri Y and Feely R, Tsukuba, Japan, October 2000.

Dickson A G and Millero F J 1987 A comparison of the equilibrium constants for the dissociation of carbonic acid in seawater media; Deep-Sea Res. 34 1733-1743.

Ducklow H W 1993 Bacterioplankton distributions and production in the northwestern Indian Ocean and Gulf of Oman, September 1986; Deep-Sea Res. II 40 753-771.

Feely R A, Wanninkhof R, Takahashi T and Tans P P 1999 Influence of El Niño on the equatorial Pacific contribution to atmospheric $\mathrm{CO}_{2}$ accumulation; Nature 398 597-601.

Feely R A, Wanninkhof R, Goyet C, Archer D E and Takahashi T 1997 Variability of $\mathrm{CO}_{2}$ distributions and sea-air fluxes in the central and eastern equatorial Pacific during the 1991-1994 El Niño; Deep-Sea Res. II 44 1851-1867.

Feely R A, Boutin J, Cosca C E, Dandonneau Y, Etcheto J, Inoue $\mathrm{H}$ Y, Ishii $\mathrm{M}$, Le Quere $\mathrm{C}$, Mackey $\mathrm{D} \mathrm{J}$, McPhaden M, Metzl N, Poisson A and Wanninkhof R 2002 Seasonal and interannual variability of $\mathrm{CO}_{2}$ in the equatorial Pacific; Deep-Sea Res. II 49 2443-2469.

Fushimi K 1987 Variations of carbon dioxide partial pressure in the western North Pacific surface water during the 1982/83 El Niño event; Tellus 39B 214-227.

George M D, Kumar M D, Naqvi S W A, Banerjee S, Narvekar P V, de Sousa S N and Jayakumar D A 1994 A study of the carbon dioxide system in the northern Indian Ocean during pre-monsoon; Mar. Chem. 47 $243-254$.

Goyet C, Millero F J, O'Sullivan D W, Eischeid G, McCue S J and Bellerby R G J 1998 Temporal variations of $\mathrm{pCO}_{2}$ in surface seawater of the Arabian Sea in 1995; Deep-Sea Res. I 45 609-624.

Goyet C, Coatanoan C, Eischeid G, Amaoka T, Okuda K, Healy R and Tsunogai S 1999 Spatial variation of total $\mathrm{CO}_{2}$ and total alkalinity in the northern Indian Ocean: A novel approach for the quantification of anthropogenic $\mathrm{CO}_{2}$ in seawater; J. Mar. Res. 57 135-163.

Haines M A, Luther M E and Fine R A 1997 Modelvalidated parameterization for air-sea gas transfer in the northern Indian Ocean; Geophys. Res. Lett. 24 $2545-2548$

Honjo S, Dymond J, Prell W and Ittekkot V 1999 Monsooncontrolled export fluxes to the interior of the Arabian Sea; Deep-Sea Res. II 46 1859-1902.

Iizuka S, Matsuura T and Yamagata T 2000 The Indian Ocean SST dipole simulated in a coupled general circulation model; Geophys. Res. Lett. 27 3369-3372.

Inoue $\mathrm{H}$, Sugimura Y and Fushimi K $1987 \mathrm{pCO}_{2}$ and $\delta^{13} \mathrm{C}$ in the air and surface seawater in the western North Pacific; Tellus 39 228-242.

Jabaud-Jan A, Metzl N, Brunet C, Poisson A and Schauer B 2004 Interannual variability of the carbon dioxide system in the southern Indian Ocean (20S-60S): The impact of a warm anomaly in austral summer 1998; Global Biogeochem. Cycles 18 doi:10.1029/2002GB002017.

Kortzinger A, Duinker J C and Mintrop L 1997 Strong $\mathrm{CO}_{2}$ emissions from the Arabian Sea during South-West Monsoon; Geophys. Res. Lett. 24 1763-1766.

Kumar M D, Naqvi S W A, George M D and Jayakumar D A 1996 A sink for atmospheric carbon dioxide in the northeast Indian Ocean; J. Geophys. Res. 101 18,121-18,125.

Le Borgne R, Feely R A and Mackey D J 2002 Carbon fluxes in the equatorial Pacific: a synthesis of the JGOFS programme; Deep-Sea Res. II 49 2425-2442. 
Lee C, Murray D W, Barber R T, Buesseler K O, Dymond J, Hedges J I, Honjo S, Manganini S J, Marra J, Moser C, Peterson M L, Prell W L and Wakeham S G 1998 Particulate organic carbon fluxes: Compilation of results from the 1995 US JGOFS Arabian Sea Process Study; DeepSea Res. II 45 2489-2501.

Levitus S, Antonov J I, Boyer T P and Stephens C 2000 Warming of the World Ocean; Science $\mathbf{2 8 7}$ 2225-2229.

Levitus S, Antonov J I, Wang J, Delworth T L, Dixon K W and Broccoli A J 2001 Anthropogenic warming of Earth's climate system; Science 292 267-270.

Lewis E and Wallace D W R 1998 Program developed for $\mathrm{CO}_{2}$ system calculations, Rep. ORNL/CDIAC-105, Carbon Dioxide Inf. Anal. Cent., Oak Ridge Natl. Lab., U.S. Dept. of Energy, Oak Ridge, Tenn.

Liu H, Campbell L, Landry M R, Nolla H A, Brown S L and Constantinou J 1998 Prochlorococcus and Synechococcus growth rates and contributions to production in the Arabian Sea during the 1995 Southwest and Northeast Monsoons; Deep-Sea Res. II 45 2327-2352.

Louanchi F, Metzl N and Poisson A 1996 A modeling the monthly sea surface $\mathrm{fCO}_{2}$ fields in the Indian Ocean; Mar. Chem. 55 265-280.

Madhupratap M, Prasanna Kumar S, Bhattathiri P M A, Kumar M D, Raghukumar S, Nair K K C and Ramaiah N 1996a Mechanism of the biological response to winter cooling in the northeastern Arabian Sea; Nature $\mathbf{3 8 4}$ 549-552.

Madhupratap M, Gopalakrishnan T C, Haridas P, Nair K K C, Aravindakshan P N, Padmavati G and Paul S 1996b Lack of seasonal and geographic variation in mesozooplankton biomass in the Arabian Sea and its structure in the mixed layer; Curr. Sci. 71 863-868.

Manghnani V, Morrison J M, Hopkins T S and Bohm E 1998 Advection of upwelled waters in the form of plumes off Oman during the Southwest Monsoon; Deep-Sea Res. II 45 2027-2052.

McCarthy J J, Garside C, Nevins J L and Barber R T 1996 New production along $140 \mathrm{~W}$ in the equatorial Pacific during and following the 1992 El Niño event; Deep-Sea Res. II 43 1065-1093.

Mehrbach C, Culberson C H, Hawley J E and Pytkowicz R M 1973 Measurement of the apparent dissociation constants of carbonic acid in seawater at atmospheric pressure; Limnol. Oceanogr. 18 897-907.

Meyers G 1996 Variations of Indonesian throughflow and the El Niño-Southern Oscillation; J. Geophys. Res. 101 $12,255-12,263$.

Millero F J, Degler E A, O'Sullivan D W, Goyet C and Eischeid G 1998 The carbon dioxide system in the Arabian Sea; Deep-Sea Res. II 45 2225-2252.

Morrison J M, Codispoti L, Gaurin S, Jones B, Manghnani V and Zheng A 1998 Seasonal variation of hydrographic and nutrient fields during the US JGOFS Arabian Sea Process Study; Deep-Sea Res. II 45 2053-2101.

Murtugudde R G and Busalacchi A J 1999 Interannual variability in the dynamics and thermodynamics of the tropical Indian Ocean; J. Climate 12 2300-2326.

Murtugudde R G, Sirnorini S R, Christian J R, Busalacchi A J, McClain C R and Picaut J 1999 Ocean color variability of the tropical Indo-Pacific basin observed by SeaWiFS during 1997-1998; J. Geophys. Res. 104 18,351-18,366.

Murtugudde R G, McCreary J P and Busalacchi A J 2000 Oceanic processes associated with anomalous events in the Indian Ocean with relevance to 1997-1998; J. Geophys. Res. 105 3295-3306.
Najjar R G, Sarmiento J L and Toggweiler J R 1992 Downward transport and fate of organic matter in the ocean: Simulations with a general circulation model; Global Biogeochem. Cycles 6 45-76.

Naqvi S W A, Sarma V V S S and Jayakumar D A 2002 Carbon cycling in the northern Arabian Sea during the northeast monsoon: Significance of salps; Mar. Ecol. Progr. Ser. 226 35-44.

Nicholls N 1989 Sea surface temperatures and Australian winter rainfall; J. Climate 2 965-973.

Prasad T G and McClean J 2004 Mechanisms for anomalous warming in the western Indian Ocean during dipole mode events; J. Geophys. Res. 109 doi:10.1029/2003JC 001872.

Prasad T G, Ikeda M and McClean J L 2005 Structure and mechanisms of the Arabian Sea variability during the winter monsoon; Deep-Sea Res. 52 1155-1177.

Prasanna Kumar S and Prasad T G 1996 Winter cooling in the northern Arabian Sea; Curr. Sci. 71 834-841.

Prasanna Kumar S, Ramaiah N, Gauns M, Sarma V V S S, Muraleedharan P M, Raghukumar S, Kumar M D and Madhupratap M 2001 Physical forcing of biological productivity in the northern Arabian Sea during the northeast monsoon; Deep-Sea Res. II 48 1115-1126.

Prasanna Kumar S, Madhupratap M, Kumar M D, Muraleedharan P M, de Sousa S N, Gauns M and Sarma V V S S 2001 High biological productivity in the central Arabian Sea during the summer monsoon driven by ekman pumping and lateral advection; Curr. Sci. 81 1633-1638.

Qasim S Z 1982 Oceanography of the Northern Arabian Sea; Deep-Sea Res. I 29 1041-1068.

Rao S A, Behera S K, Masumoto Y and Yamagata T 2002 Interannual subsurface variability in the tropical Indian Ocean with a special emphasis on the Indian Ocean Dipole; Deep-Sea Res. 49 1549-1572.

Rao S A, Gopalakrishna V V, Shetye S R and Yamagata T 2002 Why were cool SST anomalies absent in the Bay of Bengal during the 1997 Indian Ocean Dipole Event? Geophys. Res. Lett. 29 doi:10.1029/2001GL014645.

Sabine C L, Wanninkhof R, Key R M, Goyet C and Millero F J 2000 Seasonal $\mathrm{CO}_{2}$ fluxes in the tropical and subtropical Indian Ocean; Mar. Chem. 72 33-53.

Saji N H, Goswami B N, Vinayachandran P N and Yamagata T 1999 A dipole mode in the tropical Indian Ocean; Nature 401 360-363.

Sarma V V S S 1998 Variability in forms and fluxes of carbon dioxide in the Arabian Sea; Ph.D. thesis, Goa University, India, pp. 205.

Sarma V V S S 2002 An evaluation of physical and biogeochemical processes regulating perennial suboxic conditions in the water column of the Arabian Sea, Global Biogeochem. Cycles 16 doi:10.1029/2001GB001461.

Sarma V V S S 2003 Monthly variability in surface $\mathrm{pCO}_{2}$ and net air-sea $\mathrm{CO}_{2}$ flux in the Arabian Sea; J. Geophys. Res. 108 doi:10.1029/2001JC001062.

Sarma V V S S 2004 Net plankton community production in the Arabian Sea based on $\mathrm{O}_{2}$ mass balance model; Global Biogeochem. Cycles 18 doi:10.1029/2003GB002198.

Sarma V V S S 2005 Estimation of basin-scale euphotic zone integrated primary production using satellite chlorophyll $a$ and sea surface temperature in the Arabian Sea; J. Geophys. Res. (submitted).

Sarma V V S S, Kumar M D, George M D and Rajendran A 1996 Seasonal variability in inorganic carbon components in the central and eastern Arabian Sea; Curr. Sci. 71 852-856.

Sarma V V S S, Kumar M D and George M D 1998 The eastern and Central Arabian Sea as a perennial source for atmospheric carbon dioxide; Tellus 50B 179-184. 
Sarma V V S S, Kumar M D, Gauns M and Madhupratap M 2000 Seasonal controls on surface $\mathrm{pCO}_{2}$ in the central and eastern Arabian Sea; Proc. Indian Acad. Sci. (Earth Planet. Sci.) 109 471-479.

Schiller A, Godfrey J S, McIntosh P C, Meyers G and Fielder R 2000 Interannual dynamics and thermodynamics of the Indo-Pacific oceans; J. Phys. Oceanogr. 30 987-1012.

Schott F A and McCreary J P 2001 The monsoon circulation of the Indian Ocean; Progr. Oceanogr. 51 1-123.

Shankar D and Shetye S R 1997 On the dynamics of the Lakshadweep high and low in the southeastern Arabian Sea; J. Geophys. Res. 102 12,551-12,562.

Shetye S R, Gouveia A D and Shenoi S S C 1992 Does winter cooling lead to the subsurface salinity minimum off Saurashtra, India? In: Oceanography of the Indian Ocean (ed.) Desai B N (New Delhi: Oxford Press) pp. $617-626$.

Shukla J 1987 Interannual variability of monsoons; In: Monsoons (eds) Fein J S and Stephens P L (New York: John Wiley) pp. 399-464.

Somasundar K, Rajendran A, Kumar M D and Sen Gupta R 1990 Carbon and nitrogen budgets of the Arabian Sea; Mar. Chem. 30 363-377.

Takahashi T, Sutherland S C, Sweeney C, Poisson A, Metzl N, Tilbrook B, Bates N, Wanninkhof R, Feely R A, Sabine C, Olafsson J and Nojiri Y 2002 Global sea-air $\mathrm{CO}_{2}$ flux based on climatological surface ocean $\mathrm{pCO}_{2}$ and seasonal biological and temperature effects; Deep-Sea Res. 49 1601-1622.

Tans P P, Fung I Y and Takahashi T 1990 Observational constraints on the global atmospheric $\mathrm{CO}_{2}$ budget; Science 247 1431-1438.
Tourre Y M and White W B 1995 ENSO signals in the global upper-ocean temperature; J. Phys. Oceanogr. 25 1317-1332.

Venzke S, Latif M and Villwock A 2000 The coupled GCM ECHO-2. Part II: Indian Ocean response to ENSO; J. Climate 13 1371-1383.

Vinayachandran P N and Mathew S 2003 Phytoplankton bloom in the Bay of Bengal during the northeast monsoon and its intensification by cyclones; Geophys. Res. Lett. 30 doi:10.1029/2002GL016717.

Vinayachandran P N, Iijuka S and Yamagata T 2002 Indian Ocean dipole mode events in an ocean general circulation model; Deep-Sea Res. II 49 1573-1596.

Wanninkhof R 1992 Relationship between wind speed and gas exchange over the ocean; J. Geophys. Res. 97 7373-7382.

Webster P J, Moore A M, Loschingg J P and Leben R R 1999 Coupled ocean-atmosphere dynamics in the Indian Ocean during 1997-98; Nature 401 356-360.

Weiss R F 1974 Carbon dioxide in water and seawater: The solubility of a non-ideal gas; Mar. Chem. 2 23-25.

Wiggert J D, Murtugudde R G and McClain C R 2002 Processes controlling interannual variations in wintertime (Northeast Monsoon) primary productivity in the central Arabian Sea; Deep-Sea Res. II 49 2319-2343.

Wyrtki K 1973 Physical oceanography of the Indian Ocean; In: The Biology of the Indian Ocean, (ed.) Zeitzschel B (New York: Springer-Verlag) pp. 18-36.

Yu L and Rienecker M M 1999 Mechanisms for the Indian Ocean warming during 1997-1998 El Niño; Geophys. Res. Lett. 26 735-738.

$\mathrm{Yu}$ L and Rienecker M M 2000 Indian Ocean warming of 1997-1998; J. Geophys. Res. 105 16,923-16,939. 